\title{
Sensitivity of alpine glacial change detection and mass balance to sampling and datum inconsistencies
}

T. Goulden ${ }^{1}$, C. Hopkinson ${ }^{1,2}$, and M. N. Demuth ${ }^{3}$

${ }^{1}$ Process Engineering and Applied Science, Dalhousie University, 1360 Barrington Street, Halifax, Nova Scotia, Canada

${ }^{2}$ Cold Regions Research Centre, Wilfrid Laurier University, University Ave, Waterloo, Ontario, N2L 3C5, Canada

${ }^{3}$ Geological Survey of Canada - Cryosphere Geoscience, 601 Booth Street, Ottawa, Canada

Received: 18 October 2012 - Accepted: 12 November 2012 - Published: 2 January 2013

Correspondence to: T. Goulden (tgoulden@dal.ca)

Published by Copernicus Publications on behalf of the European Geosciences Union.

Sensitivity of alpine glacial change detection and mass balance

T. Goulden et al.

\section{Title Page}

Abstract Introduction

Conclusions

References

Tables

Figures

14

$\rightarrow$

4

Back

Close

Full Screen / Esc

Printer-friendly Version

Interactive Discussion 


\section{Abstract}

Glacial mass balance estimated through the geodetic method requires glacial surface coordinate observations from historical and contemporary sources. Contemporary observations and historical topographic maps are typically referenced to sepa-

5 rate horizontal and vertical datums and observed with different sampling intervals. This research demonstrates the sensitivity of glacial change detection to the datum considerations and sampling schemes through case studies of Andrei, Bridge and Peyto glaciers in Western Canada. To simulate the procedure of observing the glacial surfaces, profile lines were sampled from Digital Elevation Model (DEMs) on contour intervals for historical data and horizontal intervals for contemporary data. Profile lines from the following scenarios were compared: (1) different horizontal and vertical sampling schemes; (2) the horizontal datum was correctly reconciled but the vertical datum was not; (3) the vertical datum was correctly reconciled but the horizontal datum was not; (4) both the horizontal and vertical datums were correctly reconciled; and (5) both the horizontal and vertical datums were incorrectly reconciled. Vertical errors of up to $6.9 \mathrm{~m}, 6.0 \mathrm{~m}$ and $5.0 \mathrm{~m}$ were observed due to sampling effects and vertical errors of $22.2 \mathrm{~m}, 9.9 \mathrm{~m}$ and $55.0 \mathrm{~m}$ were observed due to datum inconsistencies on Bridge, Andrei and Peyto glacier respectively. Horizontal datum inconsistencies manifested as erratic levels of growth or downwasting along the glacial surface profile and vertical datum errors manifested as a consistent vertical offset. Datum inconsistencies were identified to contribute errors of up to $257.2 \times 10^{6} \mathrm{~m}^{3}$ (or $87 \%$ ) and $54.6 \times 10^{6} \mathrm{~m}^{3}$ (or $580 \%$ ) of estimated volume change below and above the equilibrium line respectively on Peyto Glacier. The results of this study provide an estimate of typical errors due to sampling constraints or datum inconsistencies as well as guidance for identifying where these error sources have contaminated mass balance results.

\section{Sensitivity of alpine glacial change detection and mass balance}

T. Goulden et al.

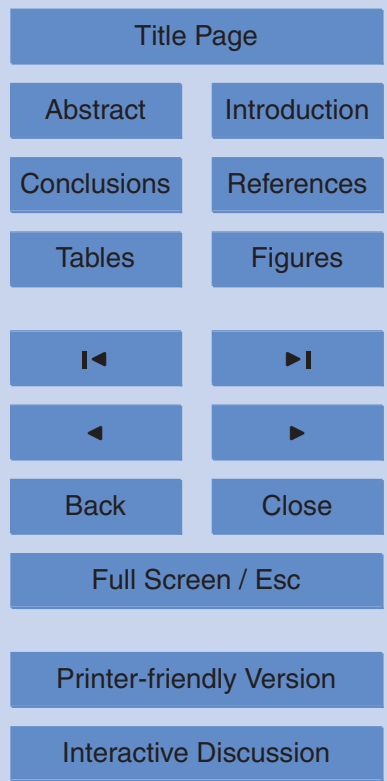




\section{Introduction}

Public interest in climate change and climate change impacts has intensified as comprehensive information on these topics (e.g. the work of the United Nations Inter-governmental Panel on Climate Change (IPCC, 2007) and the "Stern Report" 5 (Stern, 2006)) is increasingly utilized by mainstream media to illustrate and discuss the environmental and economic repercussions of present and anticipated climate change. The effective uptake and adoption of the results of climate change research by the public and policy-makers requires that the information is accompanied by adequate measures or statements of uncertainty. Moreover, it is well understood that a single case of an erroneous result can exert a negative effect on what is, on balance, sound, evidentiary based analysis (IPCC Secretariat, 2010).

As it concerns the behaviour of the World's mountain glaciers and the ice sheets, the use of archived topographic map data and modern airborne or satellite digital terrain datasets presents to us an opportunity of unprecedented proportions - in particular, to place contemporary observations in the context of longer-term fluctuations. Surface and volume fluctuations in the world's mountain glaciers, for example, can indicate changes in climate on short time scales due to their high sensitivity to variations in temperature and precipitation (Meier, 1969; Oerlemans and Fortuin, 1992; Oerlemans, 1994; Dyurgerov and Meier, 2000; Mark and Seltzer, 2005). Indeed, the observation of the reduction of mountain glaciers is well documented and commensurate with the current rise in average global temperatures (Dyurgerov and Meier, 2000; Barry, 2006; Lemke et al., 2007; Kaser et al., 2006; Trenberth et al., 2007).

The observation that the shrinkage and disintegration of mountain glaciers is accelerating (WGMS, 2011) also has several important environmental and societal consequences. For example, the melt water from mountain glaciers is a significant contributor to the eustatic component of sea-level rise (Meier, 1984; Dyurgerov and Meier, 1997; Zuo and Oerlemans, 1997; Arendt, 2002; Rignot et al., 2003; Meier et al., 2007; Larsen et al., 2007). Moreover, runoff from the temperate alpine glaciers on most continents,

\section{Sensitivity of alpine glacial change detection and mass balance}

T. Goulden et al.

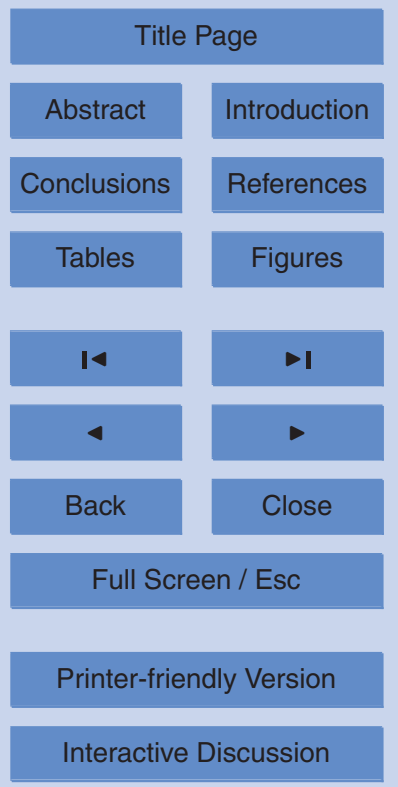


nourishes rivers and groundwater in late summer months when other contributions such as snowmelt and precipitation are in decline or may be absent all together (Meier, 1969; Fountain and Tangborn, 1985; Hopkinson and Young, 1998; Barnett et al., 2005; Demuth et al., 2008; Marshall et al., 2011). Notably, the hydrological storage 5 and flow regulation effect provided by the presence of glaciers imparts intrinsic services to the hydro-power, agriculture and mining sector, and to ecosystem functioning (Tangborn, 1984; Barnett and Lettenmaier, 2005; Vergara et al., 2007; Moore et al., 2009). Any errors introduced in the predictions of the changes to the glacial system will undermine attempts at long term planning.

\subsection{Geodetic method of mass balance}

One method of estimating glacial surface change is the indirect or geodetic method (Østrem and Brugman, 1991; Cogley et al., 2011). This method at once allows the consideration of larger glaciers and glacier systems whose measurement would be impractical using the direct or "traditional" glaciological method and, whereas employing 15 the glaciological method would only represent an estimate of the surface climatic mass balance - provides an estimate of the total mass balance needed in the context of water resource and sea-level change analyses. The geodetic method requires coordinated profile observations representative of the glacial surface between two suitable epochs be subtracted to yield the desired surface change. Observing data at a con20 temporary epoch is often performed with GPS observations (Pellikka and Rees, 2009; Mark and Seltzer, 2005), or airborne laser profiling (Echelmeyer et al., 1996; Sapiano et al., 1998; Arendt et al., 2002) in which three dimensional profile lines are created. Historical glacier profiles or surface models can be obtained by digitising contours on previously published topographic maps. A hypsometric difference profile between the 25 two surfaces can be extrapolated at discrete elevation bands across the entire glacier to facilitate an estimate of mass balance. Volume change can be estimated without the need for extrapolation if full DEMs are available at historical and contemporary epochs, such as discussed in Reinhardt and Rentsch (1986). The geodetic method has been

\section{TCD}

7, 55-101, 2013

\section{Sensitivity of alpine glacial change detection and mass balance}

T. Goulden et al.

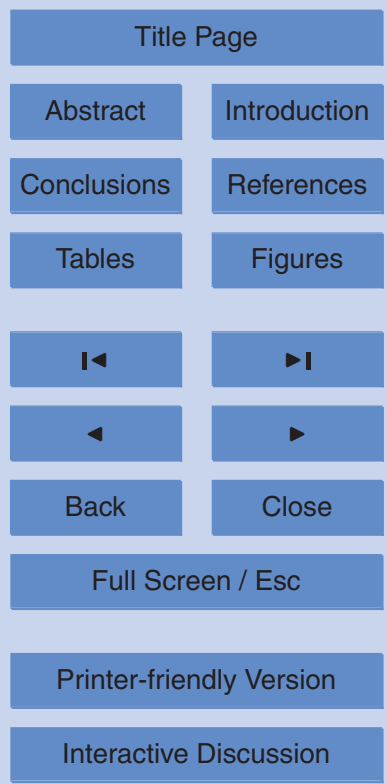

Interactive Discussion 
shown to be an accurate method for estimating mass balance when compared to the more traditional glaciological method (Tangborn et al., 1975; Kuhn et al., 1999; Cox and March, 2004).

Ideally, the geodetic method would result in the true surface change, however, 5 Cooper (1998) describes three additional reasons a change in coordinates can be observed between two separate observation epochs which include: (1) the datums for the two coordinate epochs are not identical even though the map projections may be identical; (2) errors are introduced through measurement inaccuracies; (3) errors are introduced through spatial interpolation between raw observations. This manuscript 10 intends to report on the sensitivity of the determination of glacial surface change to different datum definitions, herein referred to as the datum problem, and interpolation errors along profile measurements.

There are various measurement errors which can also affect the change detection through the geodetic method (Nuth and Kääb, 2011). For example, Khalsa et al. (2004) identify vertical errors in a glacial surface DEM derived from ASTER stereo pairs to be up to $15-20 \mathrm{~m}$, a common issue in glacial mapping due to the low image texture of the glacial surface as well as variable topography. Also, Echelmeyer et al. (1996), Sapiano et al. (1998), and Arendt et al. (2002) identify errors in contour line definition in historical topographic maps as the major limiting factor for accurate determination of surface elevation change. Although these effects are important and have been shown to be significant, they will not be given attention here as this study does not intend to investigate and quantify all sources of uncertainty. Although datum and interpolation issues have been identified as error sources in previous literature no studies have performed an analysis to determine the sensitivity of their effects to long term glacial 25 wastage and mass balance.

\subsubsection{Interpolation considerations to the geodetic method}

Interpolation error can be introduced to the geodetic method through the different sampling schemes of contemporary and historical datasets. The contemporary elevation

\section{TCD}

7, 55-101, 2013

\section{Sensitivity of alpine glacial change \\ detection and mass balance}

T. Goulden et al.

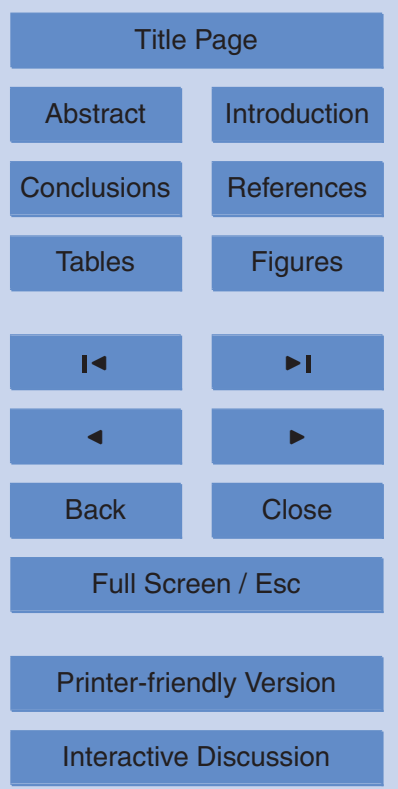

Interactive Discussion 
profiles of glacial surfaces are often observed on even horizontal intervals. This is because a field observer will pace constant spacing before acquiring a GPS fix or laser altimetry observations are performed at a constant observation frequency. Historical observations from topographic maps will typically be extracted from the inter5 section of a profile path with contour lines as a direct observation of elevation can be achieved. In the laser profiling technique introduced by Echelmeyer et al. (1996), Sapiano et al. (1998), and Arendt et al. (2002) interpolation was not a significant issue as the pulsed lasers used could transmit and receive at high frequencies resulting in ground horizontal point spacing at sub metre levels. If GPS observations are collected 10 at ground level the horizontal spacing tends to be greater because it relies on manual data collection which is time consuming at dense intervals. Therefore, contemporary observations will oversample areas of flat terrain while potentially undersampling steep areas, and historical observations will under sample flat terrain and will be dense in steep areas. Each will require an interpolation method to densify samples to common 15 locations, which will introduce error.

\subsubsection{Datum considerations to the geodetic method}

The second potential error source which is identified in this study is introduced by the evolution of horizontal and vertical datums between the acquisition of the historical and contemporary observations. During the course of historical mapping campaigns many nations have made changes to their federally recognized horizontal datums. In addition, the common historical vertical datum for referencing elevations has been mean sea level while contemporary GPS elevations are reported relative to the surface of an ellipsoid model, details on these effects are discussed later. The potential inconsistency between both horizontal and vertical datums is a critical consideration for glacial change detections as a proper reconciliation between historical and contemporary observations are required for a consistent spatial registration between the epochs (Cooper, 1998). Research into the history chronicling changes in spatial reference provides insight into the appropriate procedures for reconciling current and past spatial

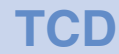

7, 55-101, 2013

\section{Sensitivity of alpine glacial change \\ detection and mass balance}

T. Goulden et al.

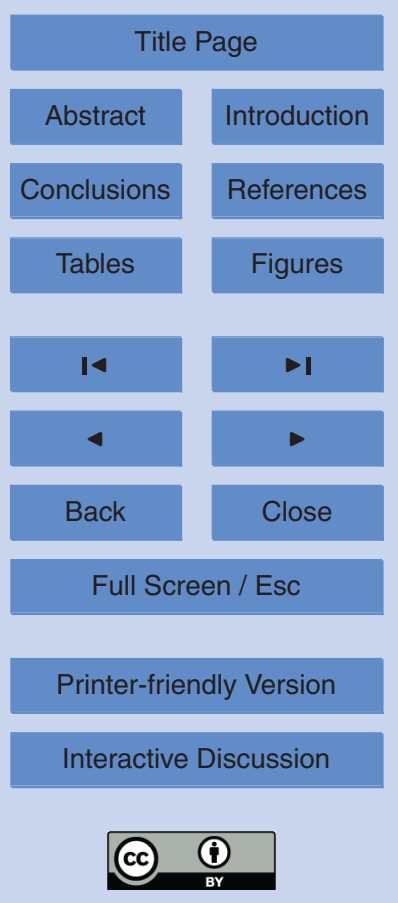


reference for different geographic and political regions as well as the typical magnitude of the error in neglecting this consideration. The reconciliation of historical datums is often challenging in nations with a well documented historical record (such as Canada and the United States), and could be a severe impediment in developing nations which 5 may not provide access or maintain records of historical datum information. Several critical areas of glaciological study do occur in developing nations such as Peru (Kaser et al., 1990), Bolivia (Kaser, 1999), Indonesian New Guinea (Kaser, 1999), Uganda (Kaser and Noggler, 1991), Tanzania (Mölg et al., 2009), and India (Kukalmi, 1992) where information on horizontal datums may be imperfectly documented.

10 As a theoretical justification for the importance of datum reconciliation consider Table 1 which summarizes representative studies of observed average surface elevation change on several glacial sites throughout the world.

Now consider Fig. 1 which displays the geoid undulation or geoid - ellipsoid separation (explained in the Data and Methods section) and a histogram of the distribution 15 these global values. The values in Fig. 1 are based on a geoid model determined from the Earth Gravimetric Model of 2008 (EGM08) and the WGS84 reference ellipsoid (NGA, 2009). If a vertical datum inconsistency exists between historical (referenced to the geoid/mean sea level) and contemporary (referenced to the ellipsoid) observations the geoidal undulation represents a vertical error that is directly introduced. Although the maximum and minimum geoidal undulations on the globe range between 86 and $-107 \mathrm{~m}$ respectively, the 5th percentile and 95th percentile of the distribution are -48.74 and $48.06 \mathrm{~m}$ respectively leaving $90 \%$ of the global values within this range (it should be noted that in glacierised mountainous areas the geoidal undulations are typically located away from the median). The representative vertical surface changes observed in Table 1 are well within the bounds of the 95th and 5th percentile range. This demonstrates that the typical melt rates that have occurred from the time historical topographic map observations were collected show changes which are not drastically different from typical global geoidal undulations. Since these values are of similar

\section{Sensitivity of alpine glacial change detection and mass balance}

T. Goulden et al.

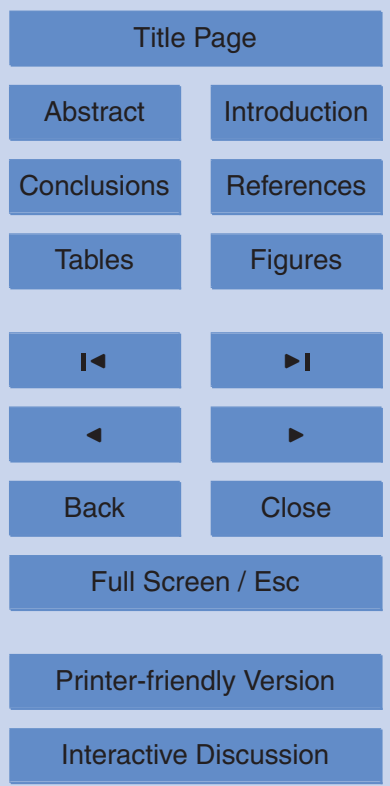


magnitude, a systematic error introduced through these inconsistencies could potentially be confused with actual change and thus bias results.

The objective of this study is to perform a sensitivity analysis of alpine glacial change detections to both interpolation error introduced through sampling bias and the datum

5 problem. It will be shown that these sources of systematic error are significant to glacial change studies performed with the geodetic method. To understand the drivers behind changes in horizontal and vertical datums a brief review of their history in a Canadian context has been provided to give readers an appreciation of the effects of change detections as well as a better understanding of the observed errors. The Canadian ex10 ample was chosen because, in addition to data availability for the three glacier study sites, Canada has a well documented record of changes made to federally recognized datums. Following this historical account, a description of the data sets used and methods for quantifying the errors is provided. Techniques for easily identifying these errors in glacial change detections using the geodetic method are provided to aid in indentify15 ing and preventing these errors from occurring in the geodetic method of glaciological mass balance.

\section{Review of datum evolution in Canada}

\subsection{Horizontal datums}

For a review of the fundamental geodetic concepts underlying horizontal and vertical datums, the reader is referred to Junkins and Garrard (1998) and Vaníček and Krakiwsky (1982). The historical importance of the evolution of both the horizontal and vertical systems is presented here to provide context for the assessment of glacial change detections to datum inconsistencies.

The North American Datum of 1927 (NAD27), and the North American Datum of 251983 (NAD83), are the only horizontal datums which have been realized as spatial reference systems across North America and officially adopted by the federal Canadian

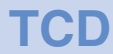

$7,55-101,2013$

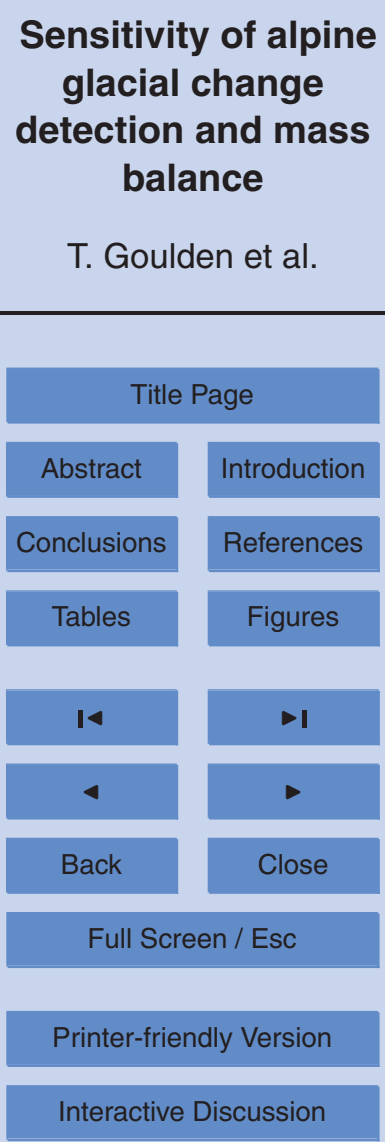

Sensitivity of alpine glacial change

\section{detection and mass}


government. A horizontal datum utilizes a three-dimensional bi-axial ellipsoid of revolution that is characterized by specific position, size and orientation parameters. Traditional geographic coordinates (latitude, longitude) are then defined with respect to the horizontal datum definition. A modification of the datum definition results in a change in 5 the datum parameters, and subsequently the same physical location on the earth's surface will be described by different geographic coordinates. Originally, the NAD27 datum was designed to model the North American continental land mass and no attempt was made to co-locate its centre with the geo-centre of the earth. As satellite global positioning technology became more prevalent in the latter decades of the twentieth century, a 10 new datum was desired which better represented the surface of the globe. The North American Datum of 1983 (NAD83) was designed to have its centre co-located with the centre of mass of the earth and used the Geodetic Reference System 1980 (GRS80) ellipsoid to best model the physical surface of the earth. In Canada, NAD83 was established and officially adopted in 1990 (Energy Mines and resources, 1990). Since 15 adoption, all map products produced by the federal government have been released according to the official horizontal and vertical datum.

To ensure legacy data originally produced in the NAD27 can be compared with contemporary data produced in NAD83, the Canadian federal government developed an official transformation model called the National Transformation Model version 2 20 (NTV2). Information on the use of this model can be found in Junkins and Farley (1995). The magnitude of the transformation between horizontal coordinates can reach hundreds of metres between the two datums and errors in the transformation can reach levels of $5-12 \mathrm{~m}$ in areas where un-modelled systematic distortions remain present (Craymer, 2006). The well known World Geodetic System 1984 (WGS84) is the datum used to produce GPS satellite orbits and raw GPS observations are tied to this datum. Both the NAD83 and WGS84 datums use the same reference ellipsoid, GRS80, and are therefore practically identical in their parameter definition. The two systems differ by only a slight offset $(\sim 2 \mathrm{~m})$ of their respective geo-centres and orientation of their

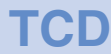

7, 55-101, 2013

\section{Sensitivity of alpine glacial change detection and mass balance}

T. Goulden et al.

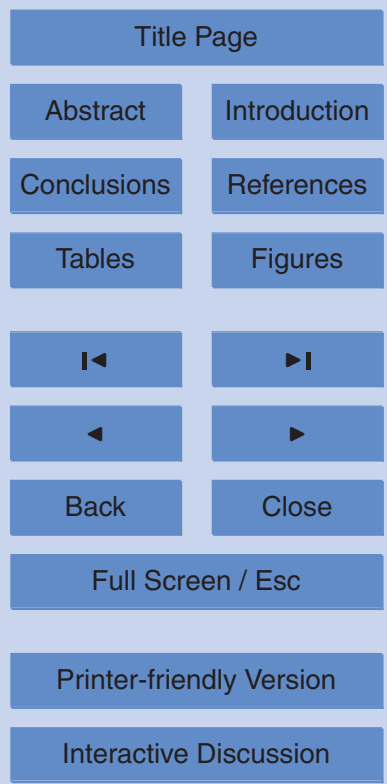


axes (Craymer, 2006). For most mapping applications, these differences can be safely ignored and the datums considered equivalent.

\subsection{Vertical datums}

Two surfaces are commonly used to reference elevations, the ellipsoid and the geoid.

5 The ellipsoid is defined by a theoretical mathematical surface which has no physical meaning. This definition can permit the apparent flow of water from lower elevations to higher elevations making it unsuitable for many applications. The geoid is a physical surface derived from the earth's gravitational potential and does not suffer from this disadvantage. The geoid is designed to be nearly coincident with mean sea level allowing direct observations to be possible through tide gauge records. Within Canada, elevations are achieved for inland areas through the densification of the vertical control network with precise levelling observations (Véronneau et al., 2006). Subsequently, all federal government mapping products are referenced to mean sea level. Since the ellipsoid is a theoretical surface, the observation of heights relative to this surface was teresting circumstance was created in which ellipsoidal heights were more efficient to obtain, yet unwanted for many applications. In response to this, Canada is developing a nation-wide geoid model which can directly convert ellipsoidal heights obtained from GPS to geoid heights with a high degree of accuracy (Véronneau, 2001; Véronneau 20 and Huang, 2007).

The official vertical datum in Canada maintains reference to mean sea level and is controlled from several tide gauge stations located on the eastern and western coasts (Véronneau et al., 2006). The mean tide is continuously observed at these stations and spirit levelling was used to densify the vertical control network inland. Observations

of this nature have been carried out since 1904 and formed the Canadian Geodetic Vertical Datum of 1928 (CGVD28) which remains as Canada's official vertical datum.

\section{Sensitivity of alpine glacial change detection and mass balance}

T. Goulden et al.

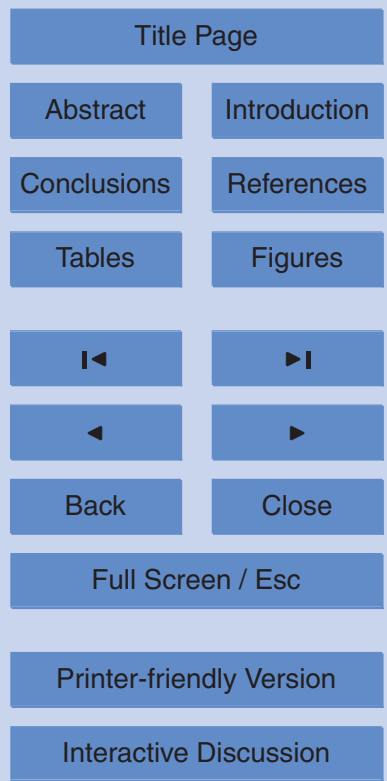




\section{Data and methods}

\subsection{Alpine glacier sites}

Three archetypal alpine glaciers from Western Canada, named Andrei, Bridge and Peyto, were chosen for the sensitivity analysis based on their varied topographic conditions, geographic location, datum conditions and data availability. Andrei and Bridge glacier are located in the northern and southern regions of the Coast Mountain chain respectively and Peyto Glacier is located in the Southern Rocky Mountain chain along the British Columbia and Alberta border. Peyto glacier is in a northern section of the Wapta Icefield and is in the headwaters of the North Saskatchewan river basin. Peyto has been well studied since its inclusion as a reference site in the 1965-1975 hydrological decade (Østrem, 2006) and its mass balance and length variations have been well documented (Demuth and Keller, 2006; Luckman, 2006). Bridge glacier is located within the Lillooet Icefield of the Southern BC Coast Mountains and the terminus is known to be retreating at an average rate of $41 \mathrm{~m} \mathrm{yr}^{-1}$ (Allen and Smith, 2007). Andrei is located in the Northern Coast Mountains and has not been well studied. It is known, in general, that alpine glaciers in these geographic regions are experiencing negative mass balances (Demuth et al., 2008; Moore et al., 2009). Under the influence of protracted negative mass balances have been the reported reductions in glacier area. For example, Bolch et al. (2010) estimate that between 1985 and 2005 glacial areas are shrinking by $10.3( \pm 3.8) \%, 7.7( \pm 3.4) \%$ and $14.8( \pm 4.1) \%$ in the Southern Coast Mountains, Northern Coast Mountains and Southern Rocky Mountains respectively. Figure 2 displays the location of the glaciers within Canada and associated nearinfrared satellite image.

Due to difficulties performing direct field observations at each of the glacial sites 25 the observations required for the geodetic method were simulated in a GIS environment. The required profiles are obtained from digital elevation model (DEM) representations of the true glacial surface. Historical profiles were simulated from DEMs that were obtained from GeoBase for Andrei and Bridge glacier. British Columbia's Terrain

\section{Sensitivity of alpine glacial change detection and mass balance}

T. Goulden et al.

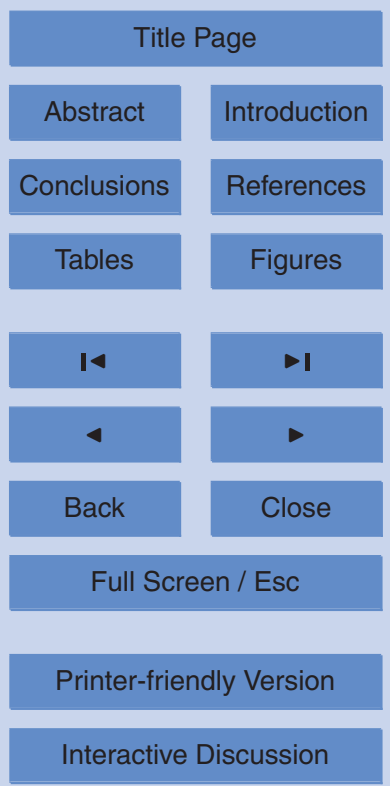


Resource Information Management (BC TRIM) database was identified as the original source of the information. Details on this dataset can be found at http://archive.ilmb. gov.bc.ca/crgb/products/mapdata/trim_positional_maps.htm. In house historical DEM information for 1966, derived from photogrammetric analysis, was available for Peyto 5 Glacier (Hopkinson et al., 2012). Contemporary profiles are obtained from a recent DEM acquisition of each of the glacial surfaces by LiDAR surveys conducted in 2006 (Demuth, 2006). A comparison of photogrammetric- and LiDAR-derived DEM attributes in alpine glacierised watersheds in this region was provided by Hopkinson et al. (2009). Table 2 provides a summary of the three glacial sites with the available datasets, the method of data collection, and the original horizontal and vertical datum.

\subsection{Determination of glacial change under different sampling and datum scenarios}

Profile lines can be digitally overlaid on the DEM of the glacial surface and the elevations can be extracted along the length of the profile. The digital profile lines that were 15 used are shown on a satellite image and LiDAR derived DEM in Fig. 3. The profiles begin at the toe of each glacier and approximately follow the centreline of the glacial surface to the highest elevation point the datasets would allow.

The profiles obtained from the historical DEMs were digitally sampled on a $20 \mathrm{~m}$ contour interval to simulate acquisition from the historical topographic map. The $20 \mathrm{~m}$ contour interval was chosen because it is the typical interval on the published topographic map series that was produced from the same information as the DEMs. The surface profiles of contemporary datums were sampled on an even horizontal interval of $100 \mathrm{~m}$ to simulate a reasonable distance for field sampling with GPS.

To create profiles which contain coincident sampling locations both the historical 25

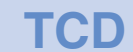

$7,55-101,2013$

\section{Sensitivity of alpine glacial change \\ detection and mass balance}

T. Goulden et al.

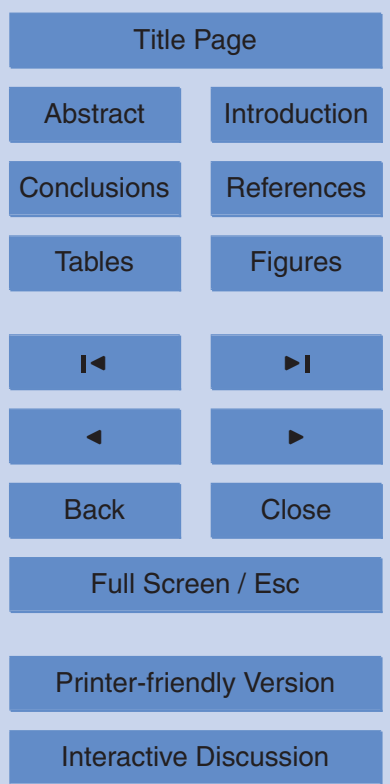


information about the topographic structure of the surface. Figure 4 displays the profile line simulation procedure.

With the profiles sampled to a common interval each spatially coincident discrete observation can be subtracted to quantify the elevation change along the entire pro-

5 file of the glacial surface. Notice in Fig. 4c the ability of the contour sampling scheme to better represent portions of the surface which are steeply sloped and the ability of the horizontal sampling interval to represent areas which are flat. The most obvious discrepancy occurs between sampling schemes near the toe of the glacier at this particular site because it terminates in a flat river basin. The horizontal sampling technique 10 was able to characterize this terrain feature, but the contour sampling interval was not because the area of coincident DEM coverage did not extend below the next lowest contour interval.

To provide a direct quantitative estimate of the magnitude of errors due to sampling and datum shifts at each glacier, four separate error scenarios of the profiles were 15 considered as follows:

1. Profiles that differ only by the sampling scheme (horizontal vs. contour)

2. Profiles with the same vertical datum but different horizontal datums (NAD27 vs. NAD 83)

3. Profiles with the same horizontal datum but different vertical datums (geoid vs. ellipsoid)

4. Profiles with different horizontal (NAD27 vs. NAD83) and vertical datums (geoid vs. ellipsoid)

and a correct profile assessment was determined when

5 Profiles obtained using the same sampling scheme and datum.

Scenario five represents the correct vertical change between the two epochs and provides a basis for assessing the error magnitudes when the datum inconsistency scenarios are incorrectly applied. This is the control dataset.

\section{Sensitivity of alpine glacial change detection and mass balance}

T. Goulden et al.

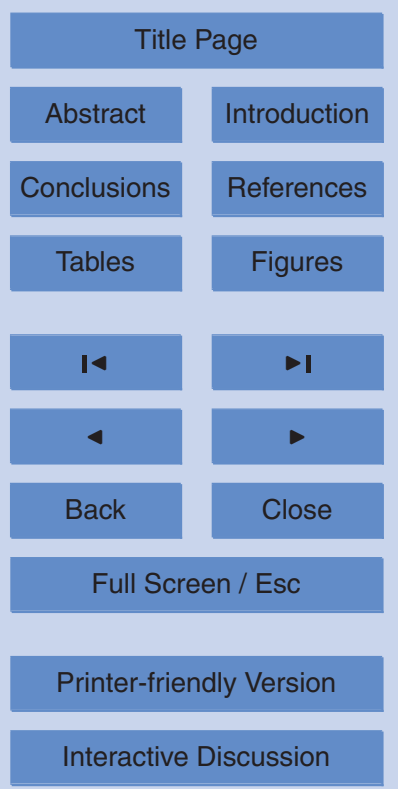


The conversion of the DEM datasets between horizontal datums was performed within ESRI GIS software which contains built in algorithms for applying the NTv2. Table 3 shows the horizontal translation between datums experienced at each of the glacial sites. In this area of North America the shift is primarily in the southern direc5 tion and with magnitude of nearly $220 \mathrm{~m}$. Although the exact value of the shift varies marginally within the boundaries of each site the variation is well within the noise level of the observations used to determine the DEM and therefore the shift is assumed to be constant within each site. This assumption may not be appropriate for larger geographic regions.

10 The conversion between vertical datums is performed by shifting all the elevations by the geoidal undulation defined as follows:

$h=H+N$

where $h$ is the ellipsoidal height, $H$ is the orthometric height (height above geoid) and $N$ is the geoidal undulation. Equation (1) shows that a positive geoidal undulation occurs 5 when the ellipsoid is vertically above the geoid and a negative geoidal undulation occurs when the geoid is vertically above the ellipsoid. The geoidal undulation for profile extents along the centre of the glacial margin and a cross-section of the glacial margin were obtained from GPS-H, a software package available from Natural Resources Canada which provides an interface for accessing the CGG2000 and CGG2005 geoid 20 models. The geoidal undulation for each glacial site are presented in Table 4 and represent the height difference between the WGS84 (GRS-80) reference ellipsoid and the CGG2000 geoid model.

The variation in geoid height is small within each glacial margin; however, larger variations occur between sites. The variation within each glacial site is below the noise level of the data $(<0.5 \mathrm{~m})$ and therefore can be safely approximated as a single constant shift; however this may not be appropriate for larger geographic regions. Andrei Glacier represents an atypical scenario in which the ellipsoid and geoid are nearly coincident allowing the conversion to be effectively ignored. The magnitude of the geoidal

\section{TCD}

$7,55-101,2013$

\section{Sensitivity of alpine glacial change \\ detection and mass balance}

T. Goulden et al.

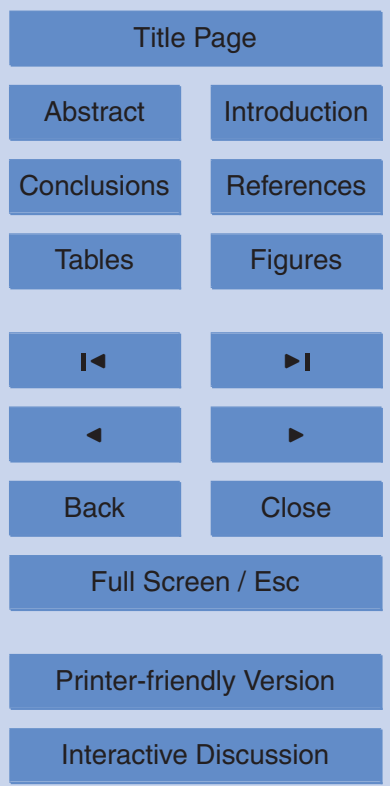

Interactive Discussion 
undulation for Bridge and Peyto Glacier is large relative to potential changes and must be considered.

The error in the five datum scenarios was quantified by subtracting profiles under the conditions of no time change as well as between the two epoch dates described in

5 Table 1. The consideration of no time change provides a quantitative error estimate that eliminates the complications introduced by the true surface change, and allows for the datum and profile sampling errors to be isolated. For the surface change analysis between the two epoch dates described in Table 2, the correct change profile (scenario 5) was determined and compared with the incorrect surface change profiles described in 10 scenario two, three and four. An error ratio was determined as an additional quantitative estimate for the surface change between the two epochs which was the difference between the correctly observed surface change (scenario 5 ) divided by the difference between the correct and incorrect profiles (scenarios 2-4).

\subsection{Estimation of mass balance under different datum scenarios}

15 To provide an estimation of the mass balance implications of the datum errors the full LiDAR derived DEM of Peyto surveyed in 2006 and the historical Peyto 1966 DEM were used. Peyto was chosen because data were available for a longer time interval between epochs and because it is a well studied site with yearly mass balance information. The entire DEM cover for each epoch was compared as opposed to the 20 profile line approach of the previous analysis. An approach to glacial mass balance using the entire DEM has been successful for water resource assessment in previous studies such as Hopkinson and Demuth (2006) and Kohler et al. (2007) and methods for utilizing entire DEMs for volume changes in glaciers can be found in Reinhardt and Rentsch (1986). The complete DEM provides a more detailed quantification of the 25 surface change throughout the glacial system in contrast to single profile lines. Each DEM contained elevations with cells which were $2.5 \times 2.5 \mathrm{~m}$ in size.

To estimate the mass balance an approximation of the equilibrium line altitude (ELA) was required to separate the zones of the glacier where losses are primarily snow and

\section{Sensitivity of alpine glacial change \\ detection and mass balance}

T. Goulden et al.

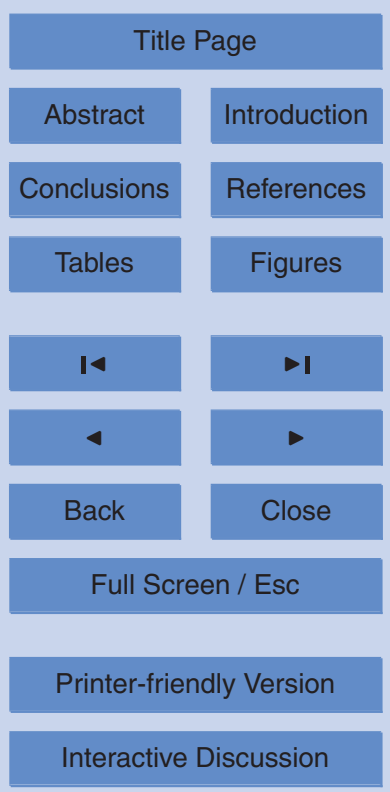


firn (above ELA) or ice (below ELA). For simplicity, and based on field records collected as part of the Peyto mass balance program, it is assumed that volume lost above the ELA has a low density of $30 \%$ snow water equivalence (SWE), while below the ELA the volume lost has a density close to $90 \%$. The long term ELA for Peyto between 51966 and 1995 was 2695 m a.s.I (Demuth and Keller, 2006). This value was updated through a weighted averaging of yearly data up to 2006 provided by the World Glacier Monitoring Service (http://www.geo.uzh.ch/microsite/wgms/) and was estimated to be 2721 m a.s.l. .

To account for the horizontal shift of the ELA contour between the two epochs, a 10 three-dimensional section of the glacial surface at each epoch was taken above and below the ELA. This was performed by slicing the glacial surface with an imaginary horizontal plane with elevation equal to the long term ELA. Figure 5 shows this procedure for Peyto Glacier below the ELA. The process was repeated for the areas both above and below the ELA and for each datum scenario listed above. Although Reinhardt and Rentsch (1986) recommend reporting hypsometric volume changes at $100 \mathrm{~m}$ vertical intervals the interest here was the net mass balance and therefore the above and below ELA volumes were totalised. The result is a raster dataset in which each cell represents the change in the glacial surface between the epochs. The cells were summed and multiplied by their area $(2.5 \mathrm{~m} \times 2.5 \mathrm{~m})$ to calculate the volume and this was converted to water volume based on the associated SWE value. This procedure was repeated for each of the datum scenarios given above.

\section{Results and discussion}

Table 5 displays a summary of the error statistics for the surface change profiles for the different sampling and datum scenarios. The discussion will be split into sections describing each of the effects separately including, sampling and interpolation error, horizontal and vertical datum errors, the topography of the sites and the mass balance estimates made at Peyto Glacier.

\section{TCD}

$7,55-101,2013$

\section{Sensitivity of alpine glacial change detection and mass balance}

T. Goulden et al.

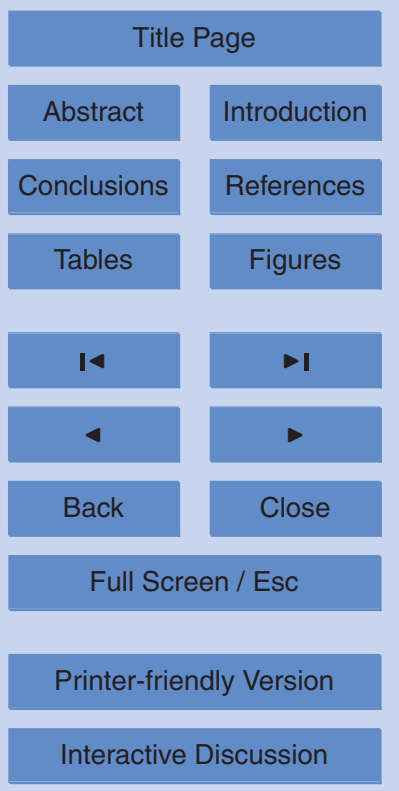

Interactive Discussion 


\subsection{Sampling and interpolation error}

Figure 6 illustrates the results of the different sampling and interpolation schemes on the surface of Bridge glacier. Bridge glacier is shown because an interesting artefact appears at the toe of the glacier which terminates on a flat proglacial outwash plain.

5 A single contour point is observable near the toe of the glacier but the elevation of the river bed does not extend below the next contour interval. Since the next available contour is not on the glacier surface the glacier terminus cannot be identified and the difference between the two surfaces cannot be accurately assessed in this area (0$1800 \mathrm{~m}$ ). This limitation prevents direct comparison of surfaces in the terminus zone between epochs.

The error magnitudes due to sampling and interpolation show variations with means of $0.01,-0.21$ and -0.39 and reach maximums of approximately $10.4 \mathrm{~m}, 6.0 \mathrm{~m}$ and $16.3 \mathrm{~m}$ on Bridge, Andrei and Peyto Glaciers, respectively (Table 5). As a linear interpolation scheme was used to densify the profile lines, the lack of data points in the flat areas (for contour points) and steep areas (for horizontal points) resulted in larger differences due to the sampling methods in these terrain types. This is evident in Fig. 6 as a highly sloped region of Bridge Glacier exists between 12000 and $13000 \mathrm{~m}$, and this area experiences the largest magnitude of error.

\subsection{Datum errors}

\subsubsection{Horizontal datum errors}

Analysis of the error in surfaces taken from the same epoch in the presence of inconsistent horizontal datums reveals abnormal variations in the profile differences that are related to the topography of the glacial surface. This is shown for the surface of Peyto Glacier in Fig. 7, which displays two surfaces from the same epoch experiencing a horizontal datum shift and consistently sampled with a contour sampling scheme to eliminate artefacts due to sampling. Under a horizontal translation, variations in topography
$7,55-101,2013$

\section{Sensitivity of alpine glacial change detection and mass balance}

T. Goulden et al.

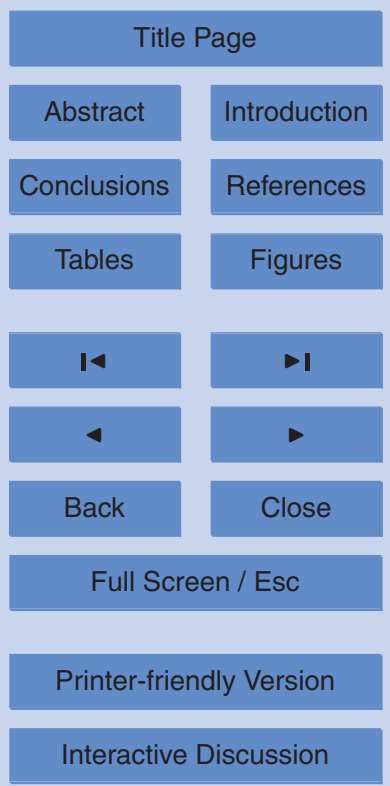


tend to create large vertical differences. Consider a natural peak in the surface of the glacier; if the correct horizontal datum transformation is implemented the two profiles will contain the peak in the same horizontal location. If the horizontal datums are not properly reconciled, the peaks in the two datasets will not be spatially coincident be5 fore subtraction and the result will be the difference in elevation between two different spatial locations. The error magnitudes due to horizontal datum inconsistency will be greater in areas of high terrain variability. In flat terrain there will be no additional error due to a horizontal datum shift as the elevations remain the same regardless of a translation. As terrain slope increases, a horizontal translation will cause increasing vertical 10 errors in the difference between the two surfaces which can be approximated as (Nuth and Kääb, 2011):

$\mathrm{d} h=a_{\tan (\alpha)}$

Where $\mathrm{d} h$ is the elevation difference due to horizontal translation, $\alpha$ is terrain slope angle, and $a$ is the magnitude of the horizontal translation. (Note: this is an approximation that assumes an equivalent and uniform terrain slope at the location compared in two surfaces.). This is evident in the section located between $3500 \mathrm{~m}$ and $4000 \mathrm{~m}$ in Fig. 7 which is highly sloped and results in the largest vertical error for the profile $(\sim 55 \mathrm{~m})$. Andrei Glacier produced the lowest mean error due to the horizontal datum shift as seen in Table 5 because it does not contain slopes as steep as either Bridge or Peyto 20 Glaciers.

When considering receding glacier surfaces observed between two epochs the prevalent elevation change should be negative (i.e. down wasting), largest near to the contemporary terminus, and decrease gradually with increasing elevation. In the presence of a horizontal datum shift the amount of change is highly variable along the profile line and does not consistently transition as the profile ascends the glacier surface. The surface change between two epochs is shown for Peyto glacier in Fig. 8a. The incorrect change profile (dotted line in Fig. 8a) shows an area of significant growth approaching

\section{Sensitivity of alpine glacial change detection and mass balance}

T. Goulden et al.

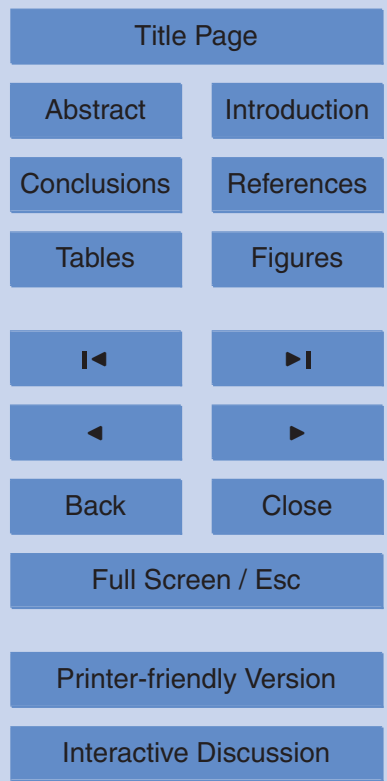


$\sim 60 \mathrm{~m}$ in the accumulation zone while the true change at the same elevation was a loss of $\sim 2 \mathrm{~m}$.

The ratio of the error to true change remains low near the modern-day terminus of the glaciers and increases with elevation, as seen for Peyto Glacier in Fig. 8b. The low 5 ratio is attributable to the large actual losses observed at lower elevations while higher ratios occur in areas of reduced elevation change. The smallest actual changes tend to be above the ELA, where Peyto and Bridge Glaciers experienced dramatic error ratios of up to $\sim 20000 \%$ and $\sim 25000 \%$, respectively. Therefore, elevation change errors, expressed as a proportion of true change, will tend to be greatest above the ELA and 10 thus most significantly impact long term accumulation estimates.

A field sampling procedure which can aid in identifying the source of horizontal datum errors on profile lines is to extend observations past the terminus of the glacier into stable regions which do not exhibit vertical changes between the two epochs (Reinhardt and Rentsch, 1986). These areas can provide valuable clues to the existence of datum errors because the unpredictable effect of the surface change has been removed. If the comparatively stable region extending downstream from the toe of the glacier is flat, then horizontal datum inconsistencies will not be apparent as there will be no elevation change under a horizontal translation. Some regions, such as those at the base of Bridge glacier may not be useful if an additional contour is unavailable to extend historical profiles. If this limitation exists, profile lines of a cross-section of the glacier that extend past the glacial boundaries into stable regions can provide similar information. In practice, stable bedrock areas may not be present in periglacial zones so caution must be exercised in all glacier DEM comparisons.

\subsubsection{Vertical datum errors}

25 The vertical datum error is represented as a constant vertical shift equivalent to the geoidal undulation because it is implemented as a constant vertical difference. The error caused by vertical datum inconsistencies will be more difficult to identify in surface change plots because it is not spatially variable and is directly coupled with the true

\section{Sensitivity of alpine glacial change detection and mass balance}

T. Goulden et al.

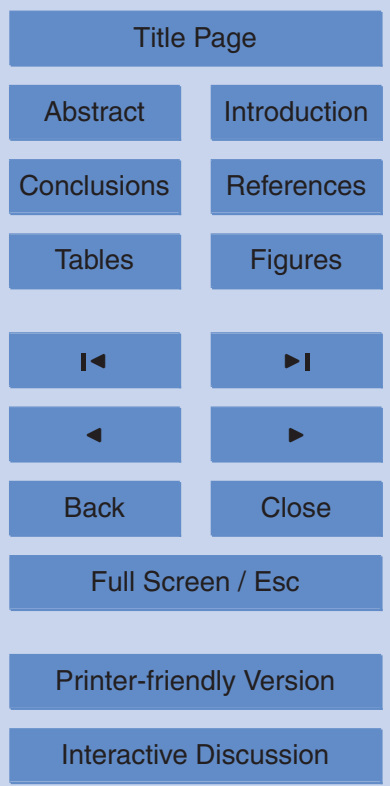


surface change. The surface change plot for a vertical datum error on Bridge Glacier is shown in Fig. 9a. The error is most easily identified in the higher elevation reaches of the glacier around the equilibrium line or past the end of the toe of the glacier in stable regions where the change should theoretically be near or equal to zero. Although the

5 magnitude of the error remained constant the ratio of this error to true surface change varied along the profile, as seen for Bridge Glacier in Fig. 9b. Similar to the horizontal datum scenario, the ratio of error increases with elevation. If only a vertical datum inconsistency exists it is easily identified in stable, non-changing regions because of the systematic shift that is consistent with the local values of geoidal undulation.

10 Surface change resulting from the combination of horizontal and vertical datum inconsistencies are a vertical shift of the horizontal datum error by the geoidal undulation. In some places, a vertical datum inconsistency will mitigate a horizontal datum inconsistency, while in others amplify it. For example, the mean error reported in Table 5 increased on Bridge and Andrei glacier when both horizontal and vertical errors were 15 inconsistent, while it decreased on Peyto. The exact result will depend on the direction of the geoid height and the orientation of the glacier relative to the shift between the horizontal datums used. Since change profiles containing both errors are similar in nature to those showing only horizontal datum inconsistencies it can be challenging to determine if both horizontal and vertical datum inconsistencies exist. Investigation into the horizontal datum inconsistencies should be undertaken first and removed if found, subsequently the existence of additional error caused by discrepancies in the vertical datum will become apparent on stable terrain.

\subsection{Topography datum interaction}

The errors caused by a horizontal or vertical datum shift are also dependent on the 25 geography of the glacial sites. The prominent aspect direction of the glacial terrain and direction of the horizontal datum shift play a critical role in the magnitude of observed error. If the glacier flow direction is in the same direction as the horizontal datum shift the datum inconsistency will reduce the amount of apparent downwasting or potentially

\section{Sensitivity of alpine glacial change detection and mass balance}

T. Goulden et al.

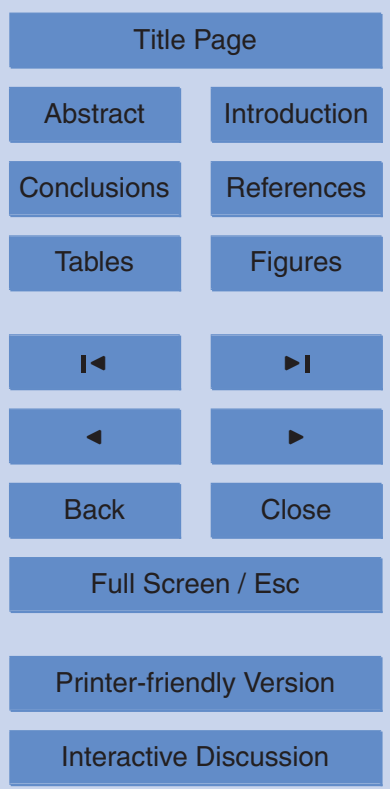


introduce surface growth. If the glacier flow opposes the direction of the horizontal datum shift, then apparent surface downwasting will increase. For example, Table 3 shows that the horizontal datum shift is primarily in a southerly direction for each of the glacial sites. The centreline profile lines on Peyto have a strong a north-south component that 5 is parallel to the direction of the horizontal datum shift while the direction of the profile lines on Bridge and Andrei more closely follow an east-west direction, perpendicular to the datum shift. As a horizontal shift perpendicular to the centreline will tend to be across a flatter surface, the error will be reduced. As a result the mean error (Table 5) on the easterly facing Andrei and Bridge Glaciers was negative and relatively small $10(<2 \mathrm{~m})$, whereas on Peyto, with its more northerly aspect, the mean error was positive and large $(\sim 28 \mathrm{~m})$.

Topography is also important when considering the geoidal undulations at each site. The geoidal undulation was near zero at Andrei, resulting in no appreciable increase in error. Both Peyto and Bridge glacier are characterized by similar values of undulation, which are generally small compared to worldwide values, especially in large mountain ranges. Also, the direction of the shift was negative, thus opposing the trend of downwasting in the actual glacial record. Had the geoidal undulation been positive, apparent downwasting would increase. Although the geoidal undulation can amount to $<50 \%$ of the change error on the tongues of Bridge and Peyto where maximum downwasting occurred the proportion will vary greatly around the world due to spatially variable geoidal undulations and different glacier melt rates. For example, on tropical glaciers where melt rates can be high, this effect may be less significant. In the Himalayas where some of the largest geoidal undulations exist, the influence of using inconsistent vertical datums on apparent surface change could exceed actual change.

\subsection{Mass balance}

Table 6 displays the results of DEM based mass balance estimates for each of the datum scenarios. The results of the analysis shown in Table 6 reveal that the mass balance calculated between the two epochs contained significant errors between the

\section{TCD}

$7,55-101,2013$

\section{Sensitivity of alpine glacial change \\ detection and mass balance}

T. Goulden et al.

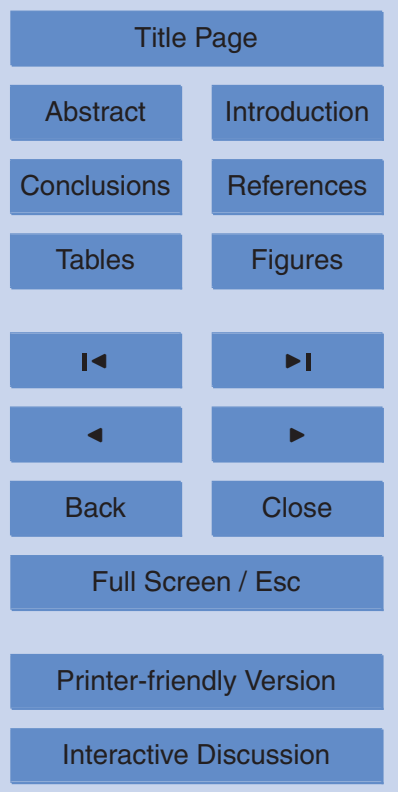


different datum scenarios. The errors were greatest below the ELA, but of note is that all incorrect datum scenarios led to proportionately larger errors that were all of incorrect sign above the ELA. Each of the incorrect datum scenarios showed a net increase in volume while the true change showed a net decrease. In addition, the area of the 5 glacier that experienced surface growth also increased in the inconsistent datum scenarios with the largest increase occurring when both the horizontal and vertical datum were not correctly reconciled. This scenario introduced an error in the estimated volume change above the ELA of $54.6 \times 10^{6} \mathrm{~m}^{3}$ or $580 \%$.

The above ELA increase in glacial mass under inconsistent vertical datums is a result 10 of the contemporary ellipsoidal reference surface being vertically above the historical geoidal reference surface. This causes erroneous growth in the surface which is equal in magnitude to the geoidal undulation. Since the natural average surface decrease occurring between the two epochs is less than the geoidal undulation an incorrectly observed growth results. Above the long term ELA the horizontal datum inconsistency caused surrounding terrain to shift into the glacial surface boundary. The orientation of the surrounding topography relative to the datum shift at Peyto caused a net growth yet downwasting could also occur in a situation of differing topographic and datum-shift alignment. Therefore, it should not be assumed that a horizontal datum shift will consistently cause decreases in the glacial wastage between two epochs, as was the case at Peyto. It must be further noted that above the long term ELA, small areas of growth were observed even when both the horizontal and vertical datums were correctly reconciled. These areas are typically on the edges of cliffs which can be attributed to residual horizontal registration issues between the DEMs of the two epochs and measurement (or interpolation) errors. The majority of error will be contributed from the 251966 photogrametrically derived DEM in which large errors are typical for high relief areas.

Below the long term ELA, downwasting in the glacier surface was apparent in all scenarios, however, the amount was reduced in each of the incorrect datum scenarios. Similar to the results above the ELA, the most significant deviation from the true change

\section{Sensitivity of alpine glacial change detection and mass balance}

T. Goulden et al.

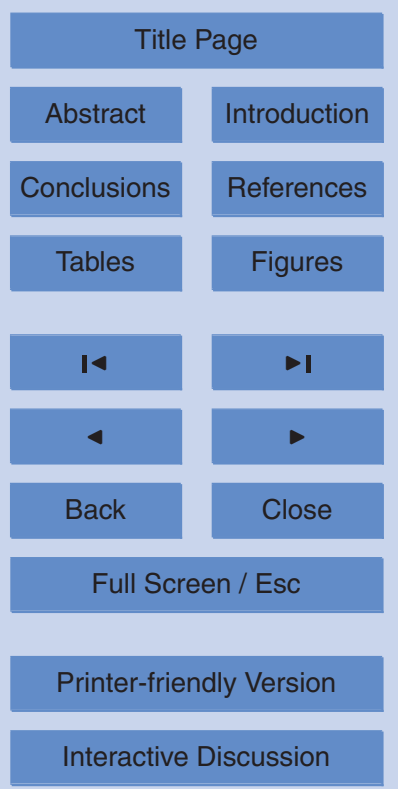


occurred when both the horizontal and vertical datums were incorrectly reconciled. This scenario resulted in an estimated volume loss error of $257.2 \times 10^{6} \mathrm{~m}^{3}$ or $87 \%$ of the true volume lost below the ELA. The inconsistency in horizontal datums led to a volumetric underestimate of $54 \%$, while the inconsistency in vertical datums led to an 5 underestimate of $30 \%$. In both above and below ELA results the largest errors were mostly due to horizontal datum inconsistency.

\section{Conclusions}

The correct assessment of glacier surface elevation change requires that historical and contemporary horizontal and vertical datums are consistent. During the historical record of observations of Canadian alpine glaciers the region has evolved through two officially adopted horizontal datums. The advent of GPS technology has introduced the ability to easily reference elevation observations to the ellipsoid while historical records typically maintain reference to the geoid. This study has illustrated the sensitivity of glacier surface change analysis to improper reconciliation of these evolving datums as well as sample interpolation error introduced by elevation profiling schemes.

Interpolation introduced through sampling generally showed minor errors which increased in areas of relatively flat or highly sloped terrain. When historical and contemporary profiles were correctly placed into a common datum, widespread glacier downwasting was observed at each of the study sites. Incorrectly referenced glacier surface profiles demonstrated significant anomalies in the quantity of downwasting and growth. For example, on a glacier centreline profile the magnitude of change between two epochs will gradually decrease from lower elevation areas to higher elevations areas. Under inconsistent horizontal datums between the two epochs the magnitude of the change will appear variable and inconsistent along the profile. A vertical dathe local ellipsoid-geoid separation. This change will manifest most significantly in the accumulation zone where true surface changes are typically small and will become

\section{TCD}

$7,55-101,2013$

\section{Sensitivity of alpine glacial change \\ detection and mass balance}

T. Goulden et al.

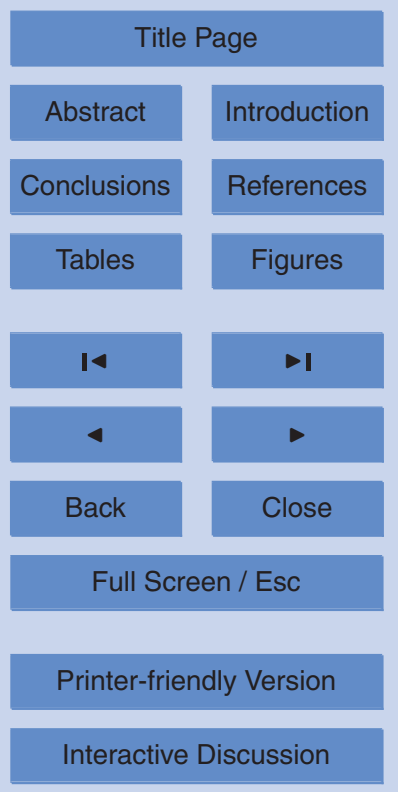


obvious if profiles are observed on stable regions past the end of the glacier's toe or adjacent stable bedrock regions.

A volume change assessment at Peyto Glacier showed a decrease in volume above and below the long term ELA, consistent with long term mass balance records (Demuth 5 and Keller, 2006). When simulated horizontal and vertical datum inconsistencies were introduced an increase apparent growth areas on the glacier surface were observed. This caused a net increase in the surface elevation above the long term ELA and a reduction in the amount of downwasting below the long term ELA. The error was most significant when both the horizontal and vertical datums not reconciled, with the in10 consistent horizontal datum contributing the majority of the error. The error was mainly caused by stable higher elevation areas being artificially moved into the glacier extent boundary, thus manifesting as an area of surface growth.

Using results contaminated by datum inconsistencies to predict the fate of a glacier or its long term runoff could lead to large and indeterminate errors. Further caution 15 should be exercised in situations where data from one or a small sample of glaciers are used to extrapolate observations across larger geographic regions, a common practice in glaciology (Hopkinson and Young, 1998; Marshall et al., 2011). Given such studies can be used to inform public policy in areas such as water resources management, understanding how such mistakes arise and knowing how to avoid or mitigate them is 20 important.

An understanding of the historical context surrounding the evolution of datums is important to identifying introduced errors and predicting how they may manifest. If anomalies in the reconstructed historical record of glacial surfaces appear during periods of known change to datum definitions, investigation into the possibility of errors in spatial reference is required. In a country such as Canada which has invested considerable resources into providing information and tools related to datum definitions the correct application of vertical and horizontal reference is not a trivial undertaking. As glacial change studies could be undertaken in areas of the world where the historical reconstruction of datum definitions and map products is not as well-documented, such

\section{Sensitivity of alpine glacial change \\ detection and mass balance}

T. Goulden et al.

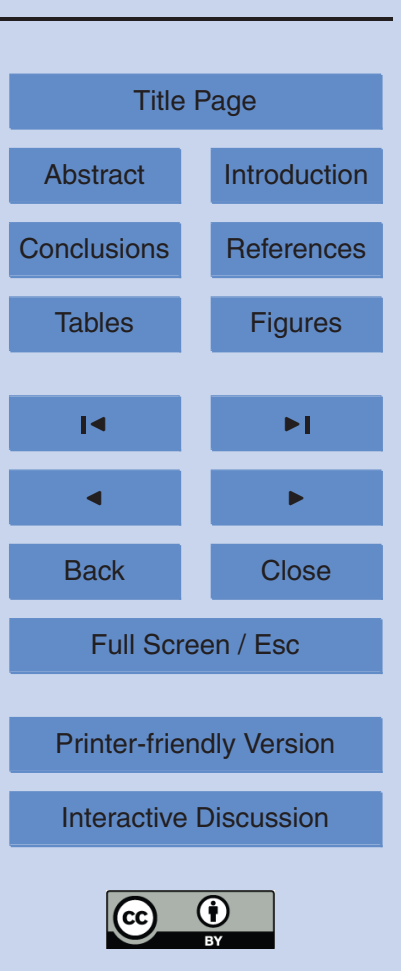


as the Andes or Himalayas, special care and research must be done to establish consistency in spatial reference.

The following findings have been identified that aid in determining if incorrect spatial referencing has occurred:

1. Surface change will appear variable and inconsistent along the centreline of the glacier.

2. Uncharacteristic losses or gains will be found in the highest elevation areas.

3. In stable regions there are irregular vertical changes in sloped surfaces or there is a systematic shift consistent with the local ellipsoid-geoid separation.

10 To properly reconcile contemporary observations obtained using GPS-based positioning with historical topographic maps and avoid inherent datum transformation errors, it is recommended that users consider the following procedure:

1. Obtain the GPS-based measurements along the desired profile.

2. Convert observed ellipsoidal heights to orthometric heights with an appropriate geoid model such as CGG2000.

3. Convert the horizontal coordinates along the profile to the historical datum using an appropriate transformation model such as the NTv2 model available from Natural Resources Canada.

4. Plot the converted coordinates on the topographic map and interpolate the associated elevations from the contour lines.

When investigating apparent errors in glacier surface change observations, it is important to remember that historical data were often observed with technology, datum definitions, and algorithms of inferior quality to contemporary data sources and thus likely contain a higher level of positional uncertainty. Therefore, it is possible that older

\section{Sensitivity of alpine glacial change detection and mass balance}

T. Goulden et al.

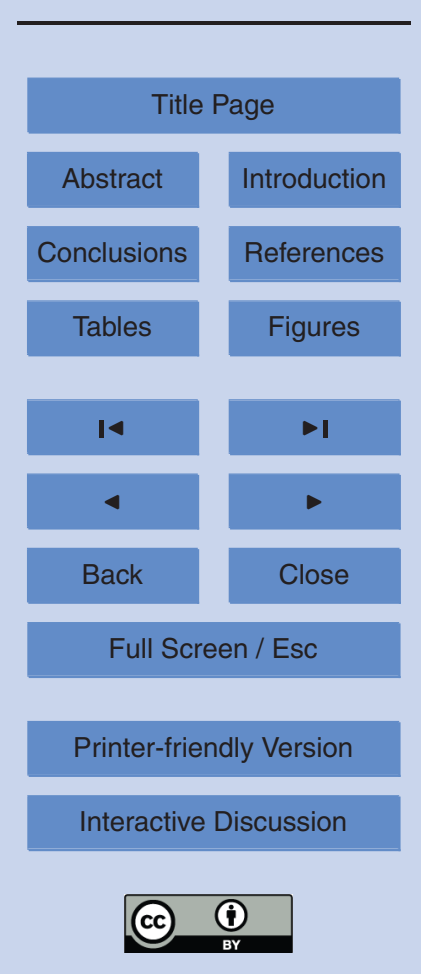


Acknowledgements. All LiDAR acquisitions were coordinated through the Canadian Consortium for LiDAR Environmental Applications Research, using an airborne laser terrain mapper 5 funded through the Canada Foundation for Innovation and operated by the Applied Geomatics Research Group, Nova Scotia. Laura Chasmer is acknowledged for supporting airborne operations. MND's NRCan GRIP funding was used to cover survey aircraft rental. Mike Demuth is supported by the NRCan/ESS Climate Change Geoscience Programme and a grant from the Canadian Space Agency, GRIP. Assistance and support for Parks Canada Agency is also

10 greatly appreciated. Tristan Goulden is supported through a National Sciences and Engineering Research Council (NSERC) PGS-D grant.

\section{References}

Allen, S. M. and Smith, D. J.: Late Holocene glacial activity of Bridge Glacier, British Columbia Coast Mountains, Can. J. Earth Sci., 44, 1753-1773, doi:10.1139/e07-059, 2007.

15 Arendt, A. A., Echelmeyer, K. A., Harrison, W. D., Lingle, C. S., and Valentine, V. B.: Rapid wastage of Alaska glaciers and their contribution to sea level rise, Science, 297, 382-385, doi:10.1126/science.1072497, 2002.

Barnett, T. P., Adam, J. C., and Lettenmaier, D. P.: Potential impacts of a warming climate on water availability in snow-dominated regions, Nature, 438, 303-309, doi:10.1038/nature04141, 202005.

Barry, R. G.: The status of research on glaciers and global glacier recession: a review, Prog. Phys. Geog., 30, 285-306, doi:10.1191/0309133306pp478ra, 2006.

Bolch, T., Menounos, B., and Wheate, R.: Landsat-based inventory of glaciers in western Canada, 1985-2005, Remote Sens. Environ., 114, 127-137, doi:10.1016/j.rse.2009.08.015, 2010.

Cogley, J. G., Hock, R., Rasmussen, L. A., Arendt, A. A., Bauder, A., Braithwaite, R. J., Jansson, P., Kaser, G., Möller, M., Nicholson, L., and Zemp, M.: Glossary of Glacier Mass Balance and Related Terms, IHP-VII Tech. Doc. Hy. No. 86, IACS Contribution No. 2, UNESCO-IHP, Paris, 2011.

\section{Sensitivity of alpine glacial change detection and mass balance}

T. Goulden et al.

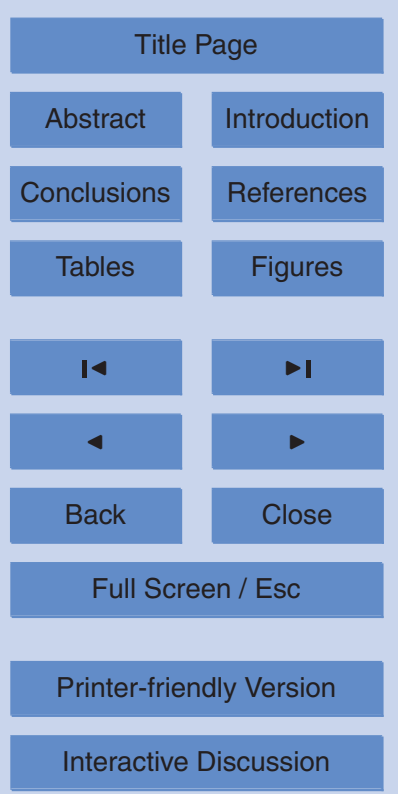

Interactive Discussion 
Cooper, M. A. R.: Datums, Coordinates and Differences, in: Landform Monitoring Modelling and Analysis, edited by: Lane, S. N., Richards, K. S., Chandler, J. H., John Wiley and Sons, West Sussex England, 21-36, 1998.

Cox, L. H. and March, R. S.: Comparison of geodetic and glaciological mass balance techniques, Gulkana Glacier, Alaska, USA, J. Glaciol., 50, 363-370, doi:10.3189/172756504781829855, 2004.

Craymer, M. R.: The Evolution of NAD83 in Canada, Geomatica, 60 , 151-164, 2006.

Demuth, M. N.: An overview of the 2006 GSC - C-CLEAR Airborne Laser Terrain Mapper mission: Selected glaciers and glacier complexes of Western Canada, Geo-referenced Digital Dataset supplied by the Applied Geomatics Research Group, COGS and through partnership with the Canadian Consortium for Lidar Environmental Applications Research under NRCan contract \# 06-00099, 9 pp. + DVD set LAS binary and x,y,z,intensity, ASC and GRD data formats.

Demuth, M. N. and Keller, R.: An assessment of the mass balance of Peyto Glacier (1966$1995)$ and its relation to recent and past-century climatic variability, in: Peyto Glacier: One century of Science, edited by: Demuth, M. N., Munro, D. S., and Young, G. J., Saskatoon, National Hydrology Research Institute (NHRI), 83-132, NHRI Science Report 8, 2006.

Demuth, M. N. , Pinard, V., Pietroniro, A., Luckman, B. H., Hopkinson, C., Dornes, P., and Comeau, L.: Recent and past-century variations in the glacier resources of the Canadian Rocky Mountains - Nelson River System, Terra Glacialis Special Issue: Mountain Glaciers and Climate Changes of the Last Century: 27-52, 2008.

Dyurgerov, M. B. and Meier, M. F.: Year-to-Year Fluctuations of Global Mass Balance of Small Glaciers and Their Contribution to Sea-Level Changes, Arctic Alpine Res., 29, 392-402, 1997.

Dyurgerov, M. B. and Meier, M. F.: Twentieth century climate change: Evidence from small glaciers, P. Natl. A. Sci., 97, 1406-1411, doi:10.1073/pnas.97.4.1406, 2000.

Echelmeyer, K. A., Harrison, W. D., Larsen, C. F., Sapiano, J., Mitchell, A. E., DeMallie, J., Rabus, B., Adalgeirsdottir, G., and Sombardier, L.: Airborne surface profiling of glaciers, a case study in Alaska, J. Glaciol., 42, 538-546, 1996.

30 Energy, Mines and Resources, Department of (EMR): New Reference System of Latitudes and Longitudes for Canada - Notice of Adoption, Canada Gazette, Part I, 124, 1808-1809, 1990.

Fountain, A. G. and Tangborn, W. V.: The effect of glaciers on streamflow variations, Water Resour. Res., 21, 579-586, doi:10.1029/WR021i004p00579, 1985. 
Foy, N., Copland, L., Zdanowicz, C., Demuth, M. N., and Hopkinson, C.: Recent volume area changes of the Kuskawulsh Glacier, Yukon Territory, Canada, J. Glaciol., 57, 515-525, 2011.

Geobase, 2011: Canadian Digital Elevation Data, http://www.geobase.ca/geobase/en/data/ cded/index.html, (last access: 25 October 2011), 2012.

5 Hopkinson, C. and Demuth, M. N.: Using airborne LiDAR to assess the influence of glacier downwasting on water resources in the Canadian Rocky Mountains, Can. J. Remote Sens., 32, 212-222, 2006.

Hopkinson, C. and Young, G. J.: The effect of glacier wastage on the flow of the Bow River, Hydrol. Process., 12, 1745-1763, doi:10.1002/(SICl)1099-

$10 \quad$ 1085(199808/09)12:10/11;1745:AID-HYP692>3.0.CO;2-S, 1998.

Hopkinson, C., Hayashi, M., and Peddle, D.: Comparing alpine watershed attributes from lidar, photogrammetric, and contour-based digital elevation models, Hydrol. Process., 23, 451463, doi:10.1002/hyp.7155, 2009.

Hopkinson, C., Demuth, M., and Sitar, M.: Hydrological implications of periglacial expansion in the Peyto Glacier catchment, Canadian Rockies, Remote Sensing and Hydrology 2010, Proceedings of a symposium held at Jackson Hole, Wyoming, USA, September 2010, IAHS Redbook Publ., 352, 2012.

IPCC: Summary for Policymakers, in: Climate Change 2007: The Physical Science Basis, Contribution of Working Group I to the Fourth Assessment Report of the Intergovernmental Panel on Climate Change, edited by: Solomon, S., Qin, D., Manning, M., Chen, Z., Marquis, M., Averyt, K. B., Tignor, M., and Miller, H. L., Cambridge University Press, Cambridge, UK and NY, NY, USA, 2007.

IPCC Secretariat: Inter-governmental Panel on Climate Change statement on the melting of $\mathrm{Hi}-$ malayan Glaciers, http://www.ipcc.ch/pdf/presentations/himalaya-statement-20january2010. pdf, (last access 3 June 2012), Geneva, CH, 20 January 2010, 2010.

Junkins, D. R. and Farley, S. A.: National Transformation Version 2, Report, Geodetic Survey Division, Natural Resources Canada, Ottawa, Canada, 1995.

Junkins, D. and Garrard, G.: Demystifying reference systems: A chronicle of spatial reference systems in Canada, Geomatica, 52, 468-473, 1998.

30 Kaser, G.: A review of the modern fluctuations of tropical glaciers, Global and Planet. Change, 22, 93-103, doi:10.1016/S0921-8181(99)00028-4, 1999.

Kaser, G. and Noggler, B.: Observations on Speke glacier, Ruwenzori Range, Uganda, J. Glaciol., 37, 313-318, 1991.

\section{Sensitivity of alpine glacial change detection and mass balance}

T. Goulden et al.

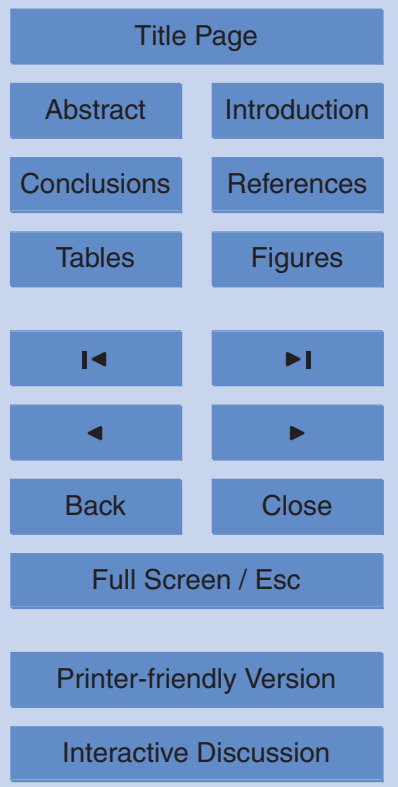


Kaser, G., Ames, A., and Zamora, M.: Glacier fluctuations and climate in the Cordillera Blanca Peru, Ann. Glaciol., No. 14, 136-140, 1990.

Kaser, G., Cogley, J. G., Dyurgerov, M. B., Meier M. F., and Ohmura, A.: Mass balance of glaciers and ice caps, consensus estimates for 1961-2004, Geophys. Res. Lett., 33, L19501, 5 doi:10.1029/2006GL027511, 2006.

Khalsa, S. J. S., Dyurgerov, M. B., Khromova, T., Raup, B. H., and Barry, R. G.: Space-based mapping of glacier changes using ASTER and GIS tools, IEEE T. Geosci. Remote S., 42, 2177-2183, doi:10.1109/TGRS.2004.834636, 2004.

Kohler, J., James, T. D., Murray, T., Nuth, C., Brandt, O., Barrand, N. E., and Aas, H. F.: Acceleration in thinning rate on Western Svalbard glaciers, Geophys. Res. Lett., 34, doi:10.1029/2007GL030681, 2007.

Kuhn, M., Dreiseitl, E., Hofinger, S., Markl, G., Span, N., and Kasar, G.: Measurements and models of the mass balance on Hintereisferner, Geogr. Ann., 81. 541-554, doi:10.1111/1468-0459.00094, 1999.

15 Kulkami, A. V.: Mass balance of Himalayan glaciers using AAR and ELA methods, J. Glaciol., 38, 101-104, 1992.

Larsen, C. F., Motyka, R. J., Arendt, A. A., Echelmeyer, K. A., and Geissler, P. E.: Glacier changes in southeast Alaska and northwest British Columbia and contribution to sea level rise, J. Geophys. Res., 112, 1-11, doi:10.1029/2006JF000586, 2007.

Lemke, P., Ren, J., Alley, R. B., Allison, I., Carrasco, J., Flato, G., Fujii, Y., Kaser, G., Mote, P., Thomas, R. H., and Zhang, T.: Observations: changes in snow, ice and frozen ground, in: Climate change 2007 - The physical science basis, Contribution of working Group I to the fourth assessment report of the international panel on climate change, edited by: Solomon, S., Qin, D., Manning, M., Chen, Z., Marquis, M., Averyt, K. B., Tignor, M., Miller, H. L., Cambridge University Press, Cambridge, 356-360, 2007.

Luckman, B. H.: The Neoglacial history of Peyto Glacier, in: Peyto Glacier - One century of science, edited by: Demuth, M. N., Munro, D. S., Young, G. J., National Hydrology Research Institute (NHRI), Saskatoon, Sask., Science Report 8, 25-57, 2006.

Mark, B. G. and Seltzer, G. O.: Evaluation of recent glacier recession in the Cordillera Blanca, 30 Peru (AD 1962-1999): spatial distribution of mass loss and climatic forcing, Quaternary Sci. Rev., 24, 2265-2280, doi:10.1016/j.quascirev.2005.01.003, 2005.

Marshall, S. J., White E. C., Demuth, M. N., Bolch, T., Wheate, R., Menounos, B. Beedle, M. J., and Shea, J. M.: Glacier water resources and forecasts for glacier decline

\section{Sensitivity of alpine glacial change detection and mass balance}

T. Goulden et al.

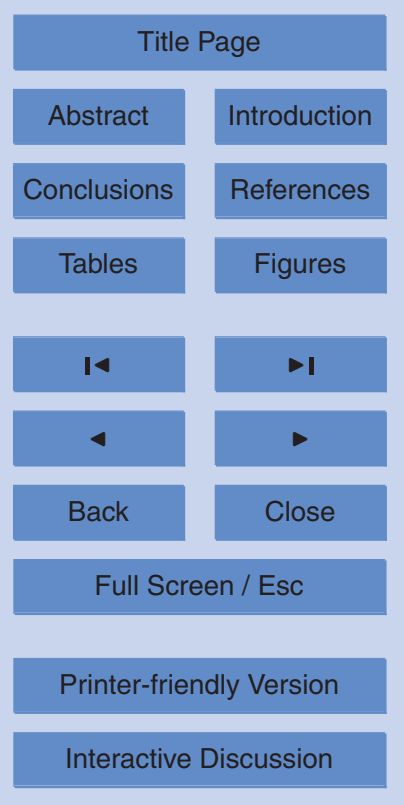


on the eastern slopes of the Canadian Rockies, Can. Water Resour. J., 36, 109-134, doi:10.4296/cwrj3602823, 2011.

Mölg, T., Cullen, N. J., Hardy, D. R., Winkler, M., and Kaser, G.: Quantifying climate change in the Tropical Midtroposphere over East Africa from glacier shrinkage on Kilimanjaro, J. Clim., $5 \quad$ 22, 4162-4181, doi:10.1175/2009JCLI2954.1, 2009.

Meier, M. F.: Glaciers and water supply, Journal of American Water Works Association, 61, 8-12, 1969.

Meier, M. F.: Contribution of Small Glaciers to Global Sea Level, Nature, 226, 1418-1421, 1984.

10 Meier, M. F., Dyurgerov, M. B., Rick, U. K., O'Neel, S., Pfeffer, W. T., Anderson, R. S., Anderson, S. P., and Glazovsky, A. F.: Glaciers dominate eustatic sea-level rise in the 21st century, Science, 317, 1064-1067, doi:10.1126/science.1143906, 2007.

Moore, R. D., Fleming, S. W., Menounos, B., Wheate, R., Fountain, A., Stahl, K., Holm, K., and Jakob, M.: Glacier Change in Western North America: Influences on Hydrology, Geomorphic Hazards and Water Quality, Hydrol. Process., 23, 42-61, doi:10.1002/hyp.7162, 2009.

NGA, 2009, EGM2008 GIS Data, http://earth-info.nga.mil/GandG/wgs84/gravitymod/egm2008/ egm08_gis.html, (last access: 25 October 2011), 2012.

Nuth, C. and Kääb, A.: Co-registration and bias corrections of satellite elevation data sets for quantifying glacier thickness change, The Cryosphere, 5, 271-290, doi:10.5194/tc-5-271$20 \quad 2011,2011$.

Reinhardt, W. and Rentsch, H.: Determination of changes in volume and elevation of glaciers using digital elevation models for the Vernagtferner, Otztal Alps, Austria, Ann. Glaciol., 8, 151-155, 1986.

Sapiano, J. J., Harrison, W. D., and Echelmeyer, K. A.: Elevation, volume and terminus changes of nine glaciers in North America, J. Glaciol., 44, 119-135, 1998.

Schiefer, E., Menounos, B., and Wheate, R.: Recent volume loss of British Columbia glaciers, Canada, Geophys. Res. Lett., 34, L16503, doi:10.1029/2007GL030780, 2007.

Stern, N.: Stern Review on the Economics of Climate Change, Cambridge University Press, Cambridge, UK, 2006

30 Tangborn, W. V.: Prediction of glacier derived runoff for hydroelectric development, Geogr. Ann., Series A, Phys. Geog., 66, 257-265, 1984.

Trenberth, K. E., Jones, P. D., Ambenje, P., Bojariu R, Easterling, D., Klein Tank, A., Parker, D., Rahimzadeh, F., Renwick, J. A., Rusticucci, M., Soden, B., and Zhai, P.: Observations:

\section{Sensitivity of alpine glacial change detection and mass balance}

T. Goulden et al.

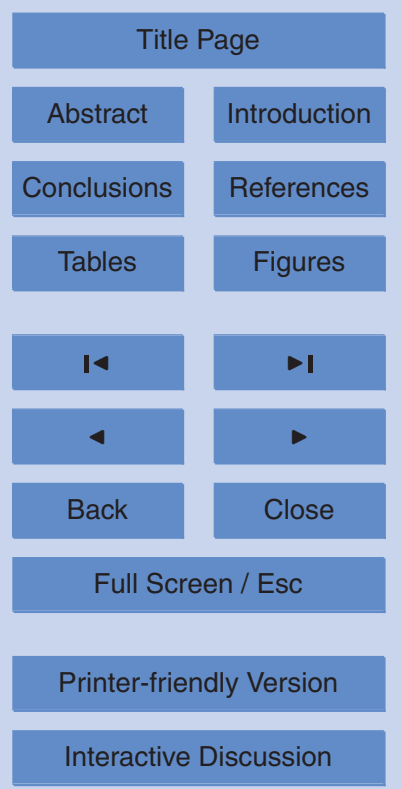


surface and atmospheric climate change,in: Climate change 2007 - The physical science basis, edited by: Solomon, S., Qin, D., Manning, M., Chen, Z., Marquis, M., Averyt, K. B., Tignor, M., Miller, H.L., Contribution of working group I to the fourth assessment report of the international panel on climate change, Cambridge University Press, Cambridge, 237-239, 52007.

Oerlemans, J.: Quantifying global warming from the retreat of glaciers, Science, 264, 243-245, doi:10.1126/science.264.5156.243, 1994.

Oerlemans, J. and Fortuin, J. P. F.: Sensitivity of Glaciers and Small Ice Caps to Greenhouse Warming, Science, 258, 115-117, doi:10.1126/science.258.5079.115, 1992.

10 Østrem, G.: History of scientific studies at Peyto Glacier, in: Peyto Glacier - One century of science, edited by: Demuth M. N., Munro, D. S., Young, G. J., National Hydrology Research Institute (NHRI), Saskatoon, Sask., Science Report 8, 1-23, 2006.

Østrem, G. and Brugman, M.: Glacier mass balance estimates, A manual for field and office work, Saskatoon, Sask., Environment Canada, National Hydrology Research Institute, NHRI

15 Science Report 4, 1991.

Pellikka, P. and Rees, G. W.: Remote Sensing of Glaciers, CRC Press, 2009.

Rignot, E., Rivera, A., and Casassa, G.: Contributions of the Patagonia icefields of South America to sea level rise, Science, 302, 434-437, doi:10.1126/science.1087393, 2003.

Tangborn, W. V., Krimmel, R. M., and Meier, M. F.: A comparison of glacier mass balance by glaciological, hydrological and mapping methods, South Cascade Glacier, Washington, Snow and Ice Symposium, Proceedings of the Moscow Symposium, August 1971, IAHSAISH Publ. No. 104, 1975.

Vaníček, P. and Krakiwsky, E. J.: Geodesy: The Concepts, North Holland Publishing Company, 1982.

Vergara, W., Deeb, A. M., Valencia, A. M., Bradley, R. S., Francou, B., Zarzar, A., Grünwaldt, A., and Haeussling, S. M.: Economic impacts of rapid glacier retreat in the Andes, EOS, 88, 261-264, 2007.

Véronneau, M., The Canadian gravimetric geoid model of 2000 (CGG2000), Report, Geodetic Survey Division, Natural Resources Canada, Ottawa, Canada, 2001.

30 Véronneau, M.: A Gravimetric Geoid Model as a Vertical Datum in Canada, Geomatica, 60, 165-172, 2006.

Véronneau, M. and Huang, J.: The Canadian gravimetric geoid model 2005 (CGG2005). Report, Geodetic Survey Division, Natural Resources Canada, Ottawa, Canada, 2007.
7, 55-101, 2013

\section{Sensitivity of alpine glacial change \\ detection and mass balance}

T. Goulden et al.

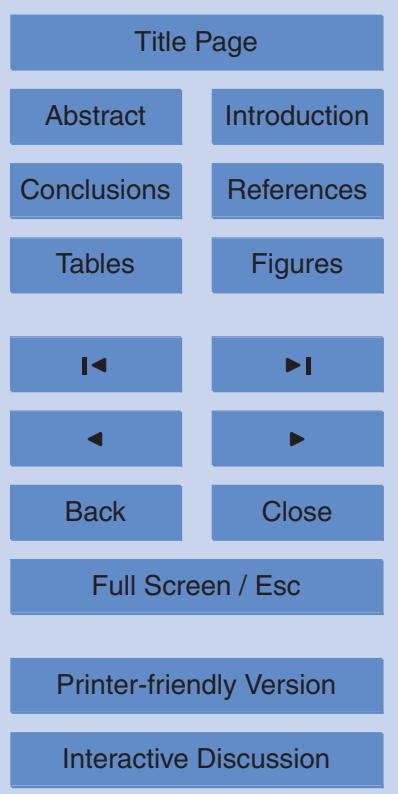

Interactive Discussion 
WGMS: Glacier Mass Balance Bulletin No. 11 (2008-2009), edited by: Zemp, M., Nussbaumer, S. U., Gärtner-Roer, I., Hoelzle, M., Paul, F., and Haeberli, W., ICSU(WDS)/IUGG(IACS)/UNEP/UNESCO/WMO, World Glacier Monitoring Service, Zurich, Switzerland, 102 pp., 2011.

5 Zuo, Z. and Oerlemans, J.: Contribution of glacier melt to sea level rise since AD 1865: a regionally differentiated calculation, Clim. Dynam., 13, 835-84, doi:10.1007/s003820050200, 1997.

TCD

7, 55-101, 2013

Sensitivity of alpine glacial change detection and mass balance

T. Goulden et al.

Title Page

Abstract Introduction

Conclusions

References

Tables

Figures

14

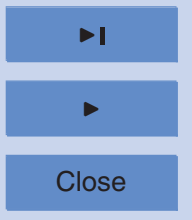

Back

Full Screen / Esc

Printer-friendly Version

Interactive Discussion 
Table 1. Representative sites of vertical glacial surface downwasting.

\begin{tabular}{lllll}
\hline Study & $\begin{array}{l}\text { Melt rate } \\
(\mathrm{m} / \mathrm{a})\end{array}$ & $\begin{array}{l}\text { Geographic } \\
\text { Region }\end{array}$ & $\begin{array}{l}\text { Years of } \\
\text { observations }\end{array}$ & $\begin{array}{l}\text { Average elevation } \\
\text { change }(\mathrm{m})\end{array}$ \\
\hline Foy et al. (2011) & 0.20 & Yukon, Canada & $1977-2007$ & 6.1 \\
\hline Rignot et al. (2003) & 1.0 & Patagonia, Chile & $1968-2000$ & 32 \\
\hline Schiefer et al. (2007) & 0.78 & $\begin{array}{l}\text { British } \\
\text { Columbia, Canada }\end{array}$ & $1985-1999$ & 10.9 \\
& & Alaska, United & $1950-1990$ & 28 \\
\hline Arendt et al. (2002) & 0.7 & States & $1974-1993$ & 34.2 \\
& 1.8 & Alaska, United & $1974-1993$ & 5.9 \\
\hline Cox and March (2004) & 0.31 & States & $1993-1999$ & 5.8 \\
& 0.96 & & & \\
\hline
\end{tabular}

Sensitivity of alpine glacial change detection and mass balance

T. Goulden et al.

Title Page

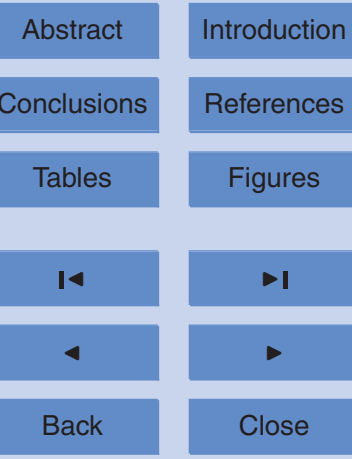

Full Screen / Esc

Printer-friendly Version

Interactive Discussion 
Table 2. Summary of the available DEM representations and spatial reference for the glacial sites.

\begin{tabular}{lllll}
\hline Glacier & Observation & Date & H Ref System & V Ref System \\
\hline Andrei & Photogrammetry & 1982 & NAD 27 & CGVD 28 \\
\cline { 2 - 5 } & LiDAR & 2006 & NAD 83 & $\begin{array}{l}\text { NAD83 } \\
\text { ellipsoid }\end{array}$ \\
\hline Bridge & Photogrammetry & 1988 & NAD 27 & CGVD 28 \\
\cline { 2 - 5 } & LiDAR & 2006 & NAD 83 & $\begin{array}{l}\text { NAD83 } \\
\text { ellipsoid }\end{array}$ \\
\hline Peyto & Photogrammetry & 1966 & NAD 27 & CGVD 28 \\
\cline { 2 - 5 } & LiDAR & 2006 & NAD 83 & $\begin{array}{l}\text { NAD83 } \\
\text { ellipsoid }\end{array}$ \\
& & & & \\
\hline
\end{tabular}

TCD

$7,55-101,2013$

Sensitivity of alpine glacial change detection and mass balance

T. Goulden et al.

Title Page

Abstract

Introduction

Conclusions

References

Tables

Figures

14

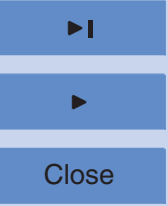

Back

Full Screen / Esc

Printer-friendly Version

Interactive Discussion 


\section{TCD}

$7,55-101,2013$

\section{Sensitivity of alpine glacial change detection and mass balance \\ T. Goulden et al.}

Table 3. Direction and magnitude of datum transformation from NAD27 to NAD83 at each glacial site.

\begin{tabular}{lll}
\hline Glacial Site & Distance $(\mathrm{m})$ & Direction $\left(^{\circ}\right)$ \\
\hline Andrei & 212.5 & 181.27 \\
Bridge & 218.7 & 180.39 \\
Peyto & 218.3 & 179.72 \\
\hline
\end{tabular}

Title Page

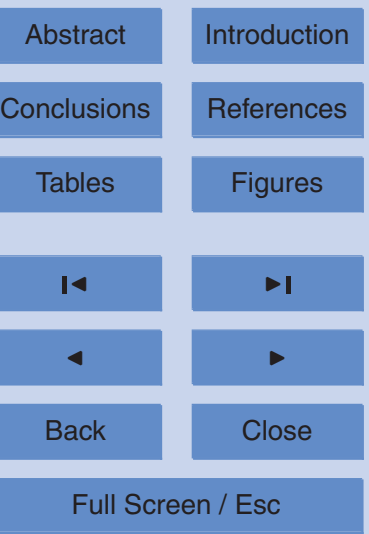

Printer-friendly Version

Interactive Discussion 


\section{TCD}

$7,55-101,2013$

\section{Sensitivity of alpine glacial change} detection and mass balance

T. Goulden et al.

Table 4. Geoid Heights at extents of analyzed profile lines.

\begin{tabular}{lr}
\hline Glacial Site & $\begin{array}{r}\text { Centreline } \\
\text { Profile }(\mathrm{m})\end{array}$ \\
\hline Andrei & 0.32 to -0.19 \\
Bridge & -12.66 to -12.80 \\
Peyto & -10.54 to -10.50 \\
\hline
\end{tabular}

Title Page

Abstract

Conclusions

Tables

14

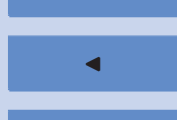

Back

Full Screen / Esc

Printer-friendly Version

Interactive Discussion 
Table 5. Summary surface change residual error for scenarios 1 to 5 for each study site.

\begin{tabular}{lrrrr}
\hline & Mean $(\mathrm{m})$ & Max $(+\mathrm{m})$ & Max $(-\mathrm{m})$ & $\begin{array}{r}\text { Standard } \\
\text { Deviation }(\mathrm{m})\end{array}$ \\
\hline Bridge Glacier Error & & & & \\
\hline 1-Sampling & 0.01 & 10.5 & -9.4 & 1.8 \\
2-H Datum & -0.62 & 22.2 & -42.5 & 13.7 \\
3-V Datum & 12.7 & 12.7 & 12.7 & 0 \\
4-H and V Datum & -13.6 & 9.2 & -55.5 & 13.7 \\
True change & -27.5 & 32.3 & -68.2 & 21.1 \\
\hline Andrei Glacier Error & & & & \\
\hline 1-Sampling & -0.21 & 6.0 & -5.3 & 1.4 \\
2-H Datum & -1.7 & 9.9 & -11.5 & 4.9 \\
True change & -61.9 & -42.6 & -100.4 & 14.3 \\
\hline Peyto Glacier Error & & & & \\
\hline 1-Sampling & -0.39 & 5.0 & -16.3 & 2.5 \\
2-H Datum & 28.1 & 55.0 & 8.3 & 11.8 \\
3-V Datum & 10.5 & 10.5 & 10.5 & 0 \\
4-H and V Datum & 17.6 & 44.5 & -2.2 & 11.8 \\
True change & -71.0 & -27.9 & -109.6 & 26.9 \\
\hline
\end{tabular}


Table 6. Estimated DEM subtraction statistics and water resource analysis under different Datum scenarios for Peyto Glacier.

\begin{tabular}{|c|c|c|c|c|c|c|c|c|}
\hline \multirow[t]{2}{*}{$\begin{array}{l}\text { Glacial } \\
\text { Zone }\end{array}$} & \multicolumn{3}{|c|}{$\begin{array}{l}\text { Average surface } \Delta \\
\text { (m) }\end{array}$} & \multicolumn{2}{|c|}{ Area $\left(\mathrm{km}^{2}\right)$} & \multirow[t]{2}{*}{$\begin{array}{l}\text { Volume } \Delta \\
\left(\times 10^{6} \mathrm{~m}^{3}\right)\end{array}$} & \multirow{2}{*}{$\begin{array}{r}\text { Water } \\
\text { volume } \\
\left(\times 10^{6} \mathrm{~m}^{3}\right)\end{array}$} & \multirow{2}{*}{$\begin{array}{l}\text { Water } \\
\text { volume } \\
\text { error (\%) }\end{array}$} \\
\hline & $+\Delta$ & $-\Delta$ & $\Delta$ & $+\Delta$ & $-\Delta$ & & & \\
\hline \multicolumn{9}{|c|}{ Consistent Horizontal and Vertical Datums (scenario 5) } \\
\hline Above ELA & 15.0 & 13.4 & -7.2 & 0.95 & 3.42 & -31.4 & -9.4 & 0 \\
\hline Below ELA & 16.8 & 38.9 & -34.7 & 0.72 & 8.79 & -330.2 & -297.2 & 0 \\
\hline Total & 15.8 & 31.8 & -26.0 & 1.67 & 12.21 & -361.6 & -306.6 & \\
\hline \multicolumn{9}{|c|}{ Inconsistent Horizontal Datum (scenario 2) } \\
\hline Above ELA & 46.8 & 20.7 & 25.8 & 2.86 & 1.29 & 107.1 & 32.1 & 441 \\
\hline Below ELA & 25.1 & 43.4 & -14.9 & 4.15 & 5.86 & -149.7 & -134.7 & 54 \\
\hline Total & 34.0 & 39.3 & -2.9 & 7.01 & 7.15 & -42.6 & -102.6 & \\
\hline \multicolumn{9}{|c|}{ Inconsistent Vertical Datums (scenario 3) } \\
\hline Above ELA & 13.2 & 6.8 & 3.3 & 2.21 & 2.16 & 14.6 & 4.4 & 147 \\
\hline Below ELA & 15.2 & 31.9 & -24.2 & 1.55 & 7.96 & -230.2 & -207.2 & 30 \\
\hline Total & 14.0 & 26.5 & -15.5 & 3.76 & 10.12 & -215.6 & -202.8 & \\
\hline \multicolumn{9}{|c|}{ Inconsistent Horizontal and Vertical Datums (scenario 4) } \\
\hline Above ELA & 50.2 & 19.1 & 36.3 & 3.32 & 0.83 & 150.8 & 45.2 & 580 \\
\hline Below ELA & 30.0 & 40.0 & -4.4 & 5.09 & 4.92 & -44.4 & -40.0 & 87 \\
\hline Total & 38.0 & 37.0 & 7.5 & 8.41 & 5.75 & 106.4 & +5.2 & \\
\hline
\end{tabular}

7, 55-101, 2013

Sensitivity of alpine glacial change detection and mass balance

T. Goulden et al.

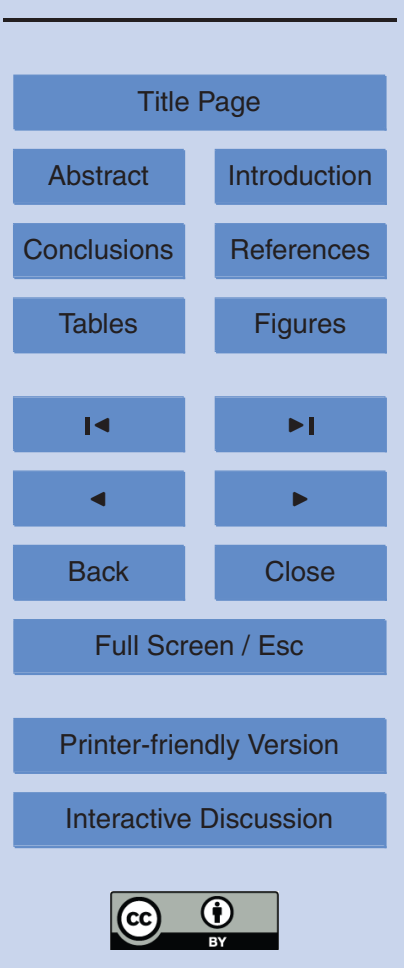



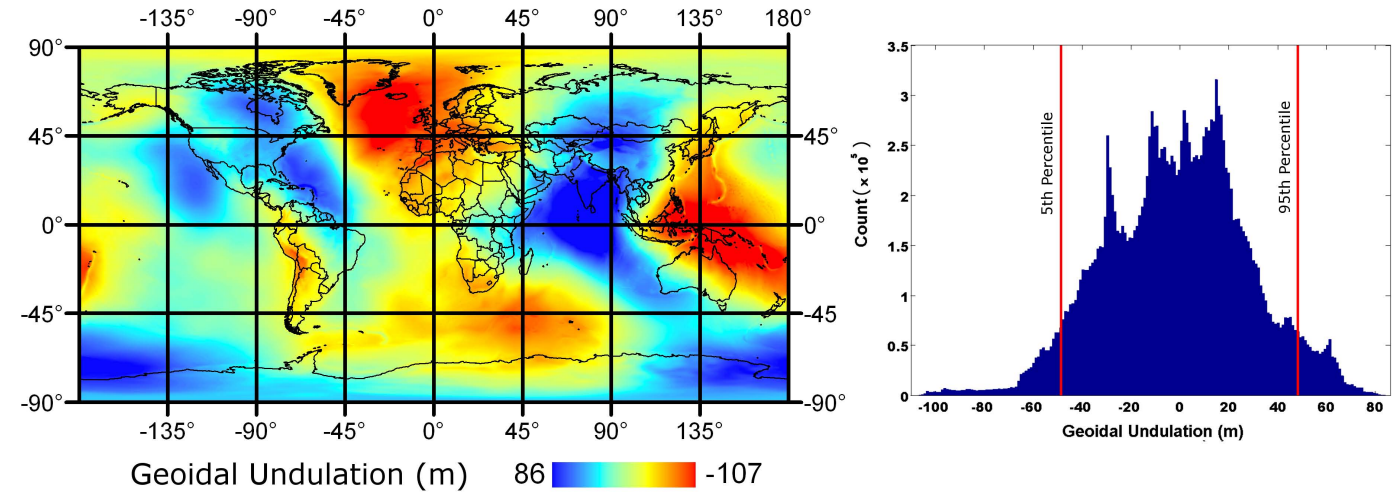

Fig. 1. Left: Global spatial distribution of geoidal undulations. Right: Histogram of geoidal undulations with red lines showing 5th and 95th percentiles. Data from NGA (2009).

\section{TCD}

$7,55-101,2013$

\section{Sensitivity of alpine glacial change detection and mass balance \\ T. Goulden et al.}

Title Page

Abstract

Introduction

Conclusions

References

Tables

Figures

14

$\rightarrow 1$

4

Back

Close

Full Screen / Esc

Printer-friendly Version

Interactive Discussion 


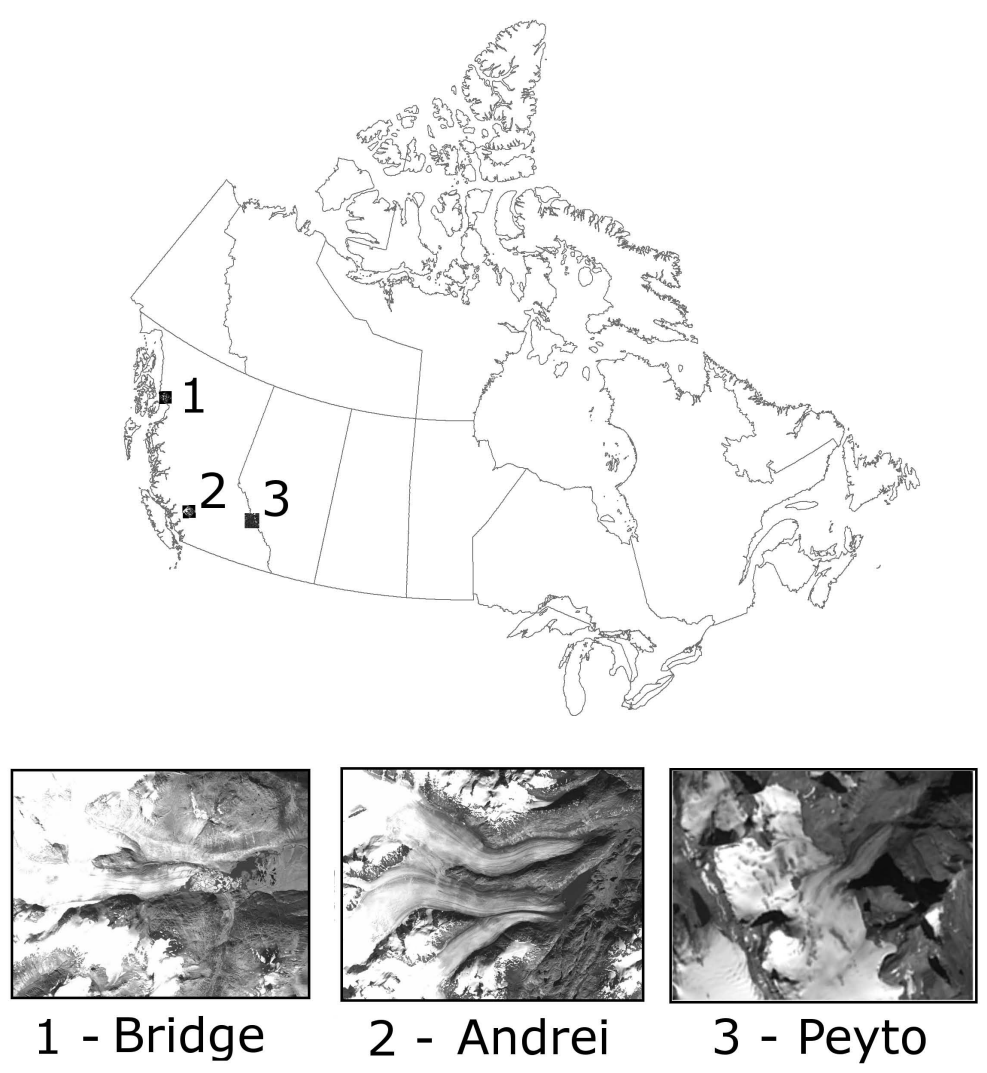

Fig. 2. Location of each of the three study sites, 1 - Bridge glacier, 2 - Andrei Glacier, and 3 Peyto Glacier and their respective location within Canada. A near infrared band satellite image is shown for each glacier (data obtained from Geobase, 2011).

\section{TCD}

$7,55-101,2013$

Sensitivity of alpine glacial change detection and mass balance

T. Goulden et al.

Title Page

Abstract

Introduction

Conclusions

References

Tables

Figures

14

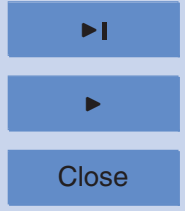

Back

Full Screen / Esc

Printer-friendly Version

Interactive Discussion 

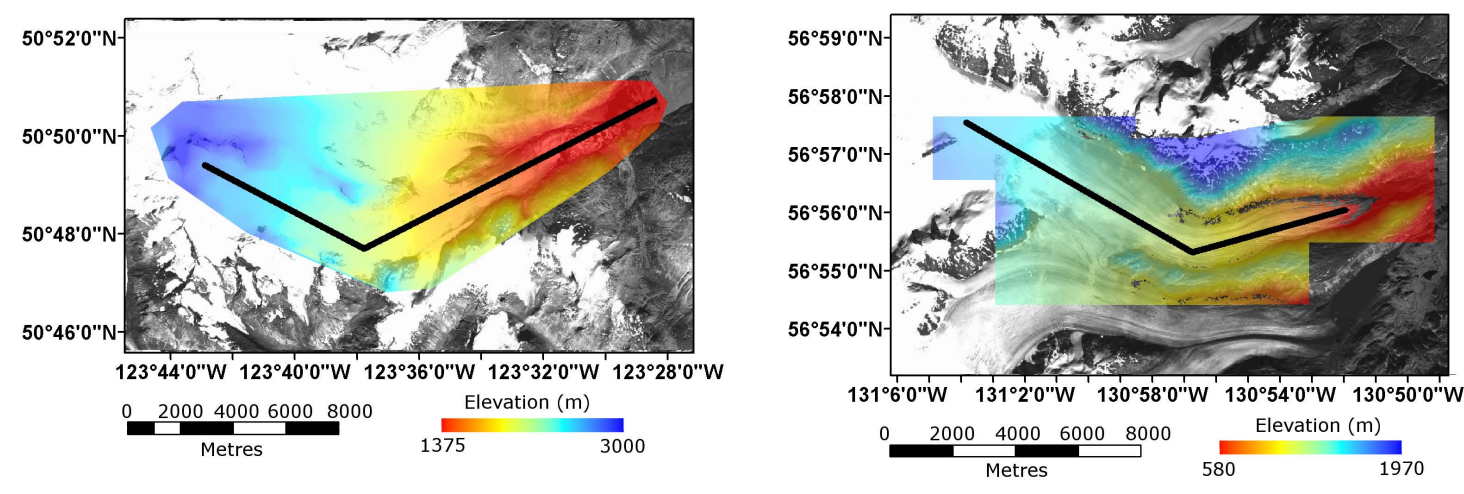

TCD

7, 55-101, 2013

\section{Sensitivity of alpine glacial change detection and mass balance}

T. Goulden et al.
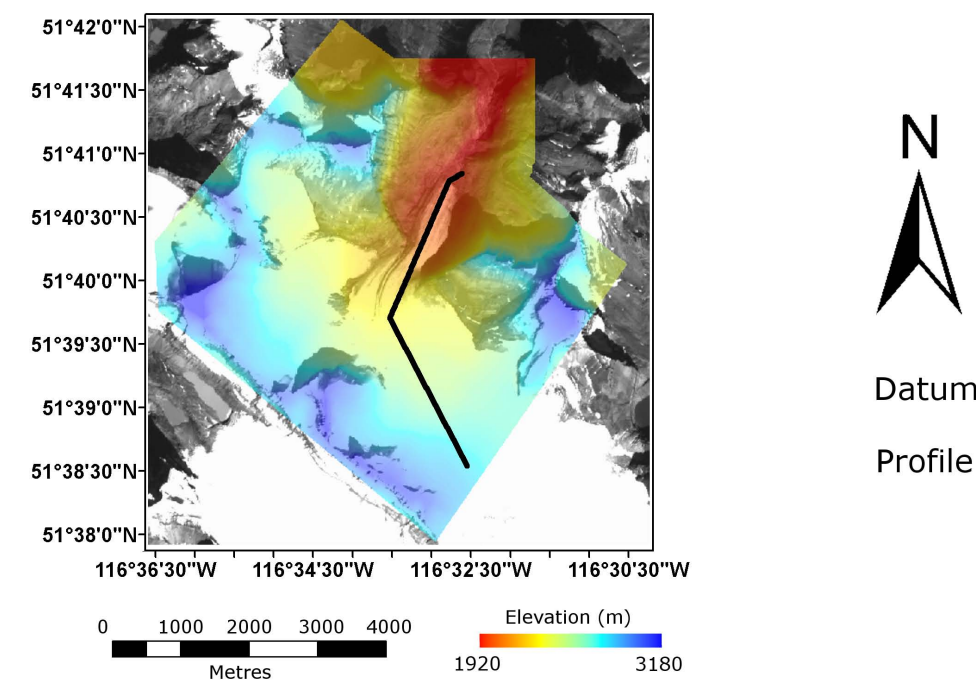

Title Page

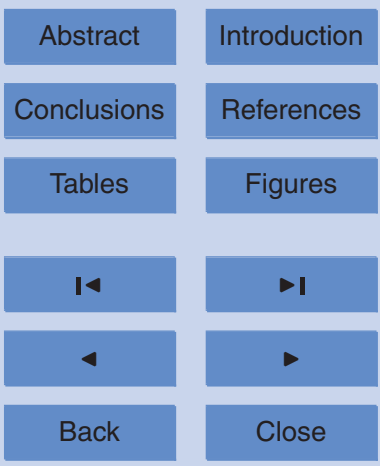

Full Screen / Esc

Printer-friendly Version

Fig. 3. Profile lines used for analysis on each glacial site. Upper left - Bridge lacier. Upper right - Andrei glacier. Lower left - Peyto Glacier.

Datum: NAD83

Profile Line

Interactive Discussion 


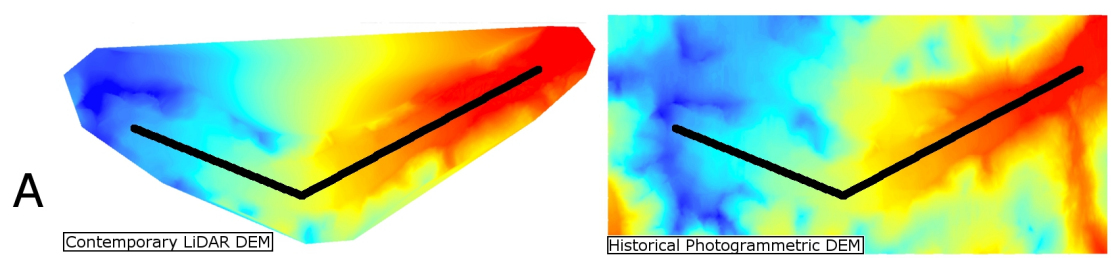

Contemporary LIDAR DEM

Profile Line
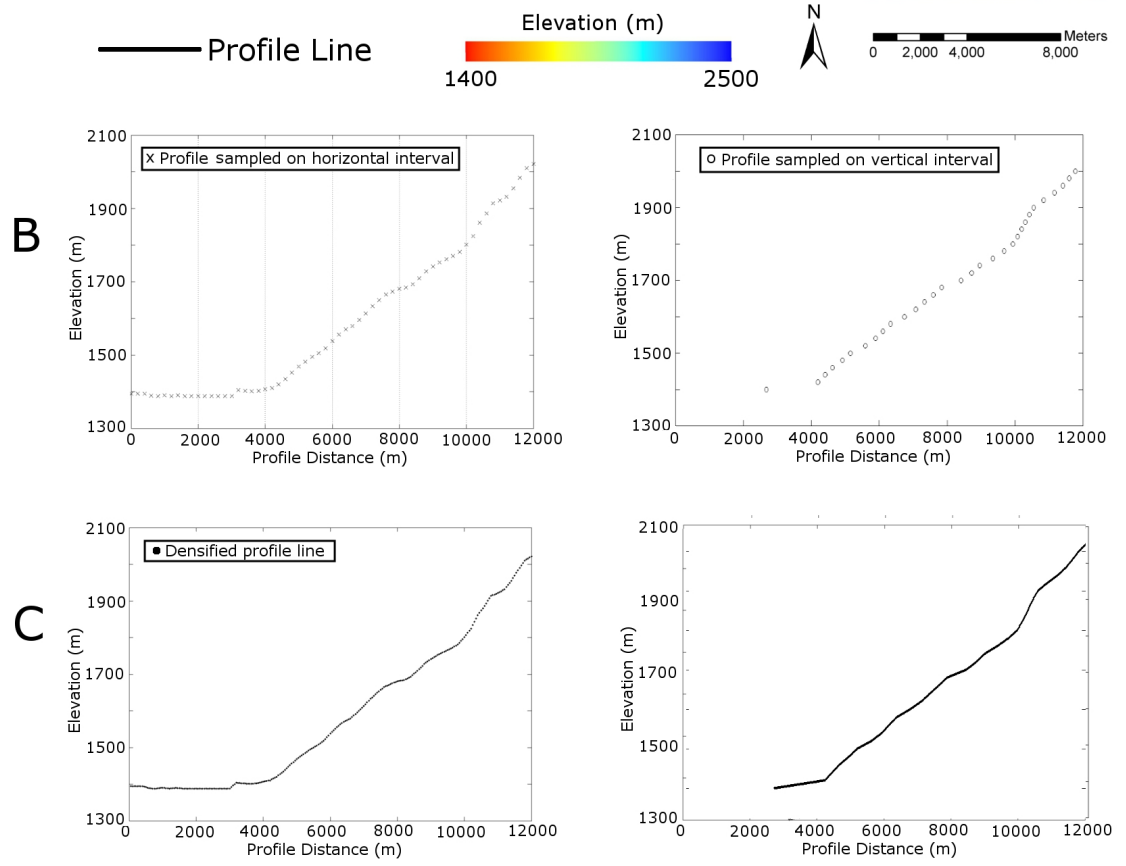

Fig. 4. Methods of simulating the geodetic method of mass balance. (A) Centreline profiles overlaid on contemporary and historical DEMs to simulate the acquisition of the elevation data (B) Horizontal and vertical sampling intervals (C) Contemporary and historical profiles respectively up-sampled to a common dense horizontal interval for subtraction.

\section{TCD}

$7,55-101,2013$

\section{Sensitivity of alpine glacial change detection and mass balance}

T. Goulden et al.

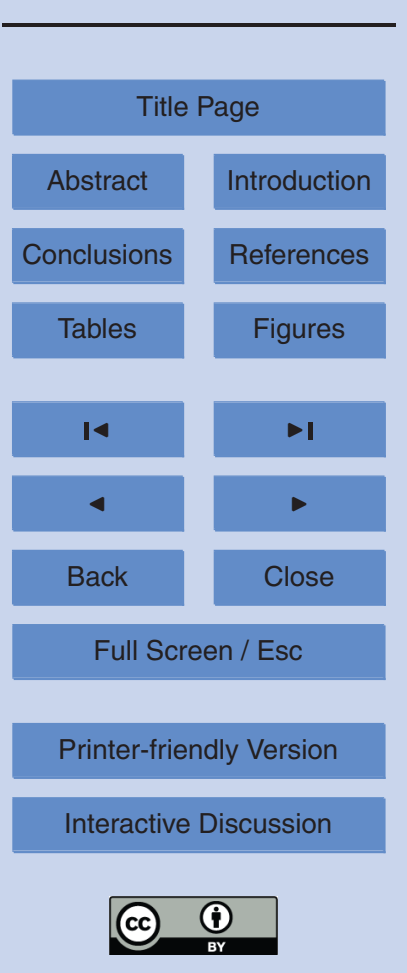


1966 Peyto Glacier DEM below ELA

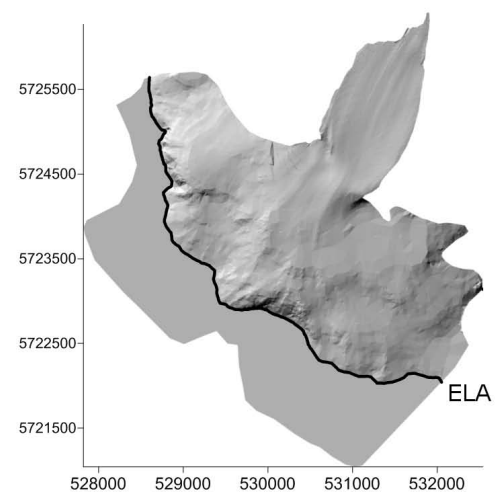

2006 Peyto Glacier DEM below ELA

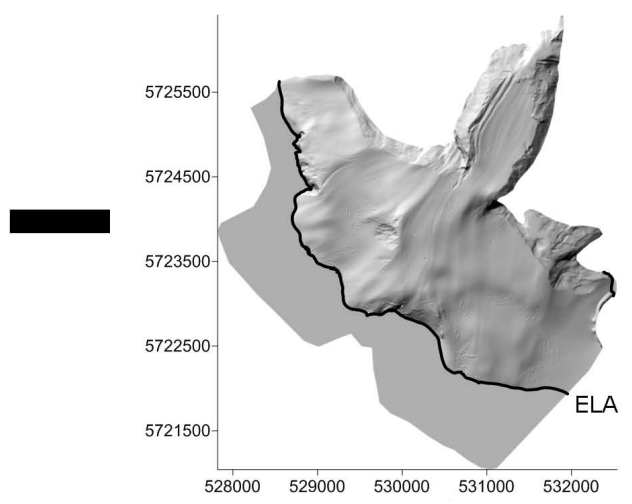

Change in glacial volume below equilibrium line altitude

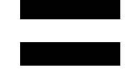

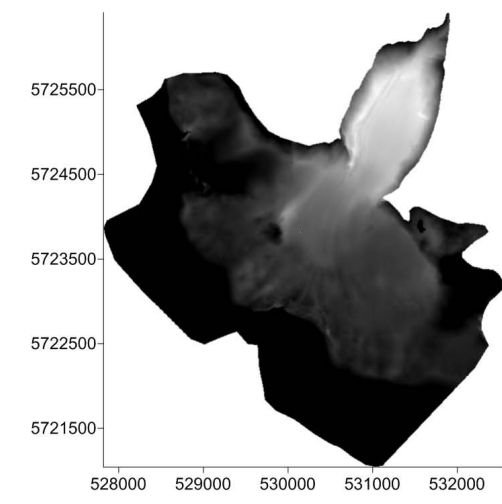

Fig. 5. Procedure for determining the change in Peyto Glacier. The DEM representation from 2006 is subtracted from the 1966 DEM representation to yield a raster of volume change, which is multiplied by an appropriate density to estimate water equivalence. This process is repeated for the volume change above the ELA.

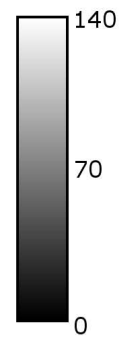

\section{TCD}

$7,55-101,2013$

Sensitivity of alpine glacial change detection and mass balance

T. Goulden et al.

Title Page

Abstract

Introduction

Conclusions

References

Tables

Figures

14

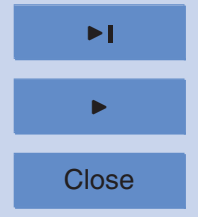

Back

Full Screen / Esc

Printer-friendly Version

Interactive Discussion 


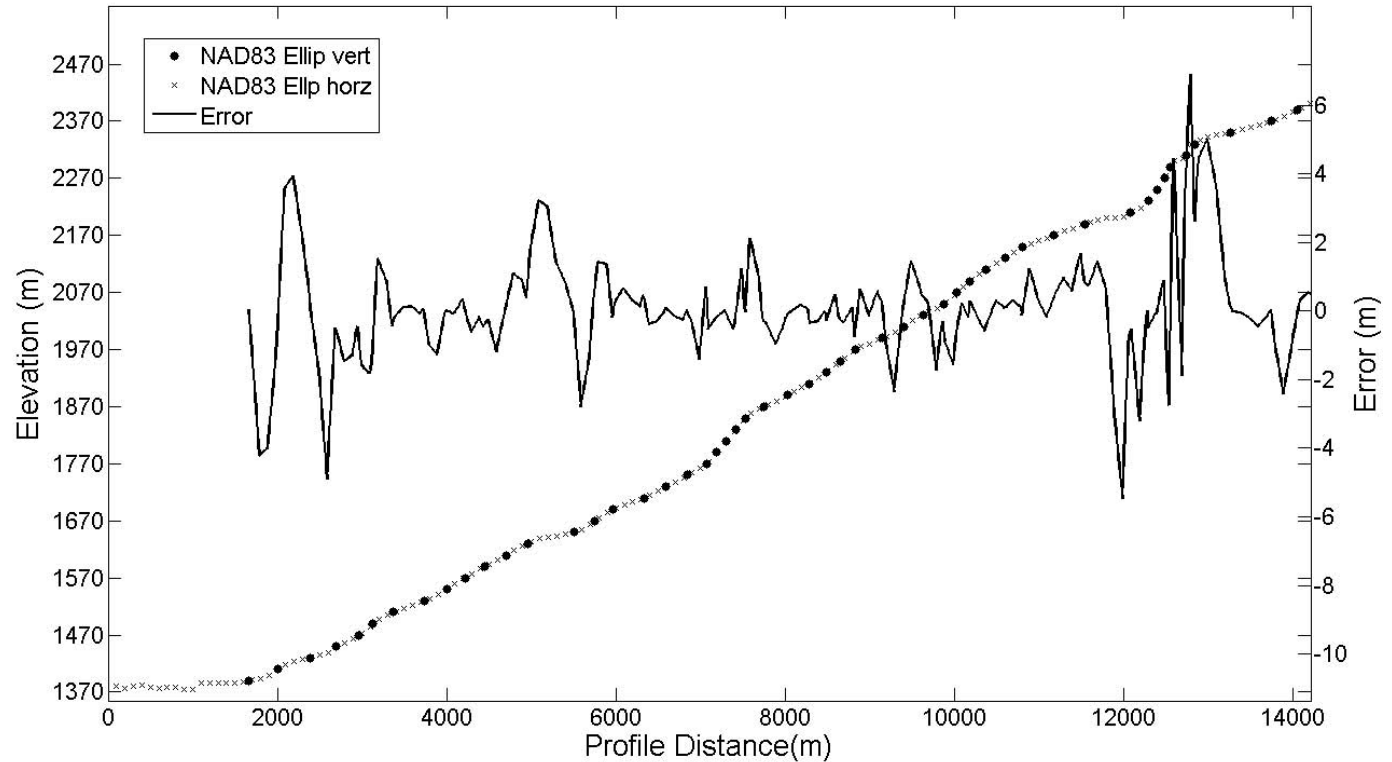

Fig. 6. Error due to sampling inconsistencies on Bridge glacier when no time change has occurred.

\section{Sensitivity of alpine glacial change detection and mass balance \\ T. Goulden et al. \\ Title Page \\ Abstract \\ Introduction \\ Conclusions \\ References \\ Tables \\ Figures \\ 14

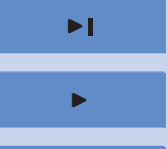 \\ Back \\ Close \\ Full Screen / Esc}

Printer-friendly Version

Interactive Discussion 


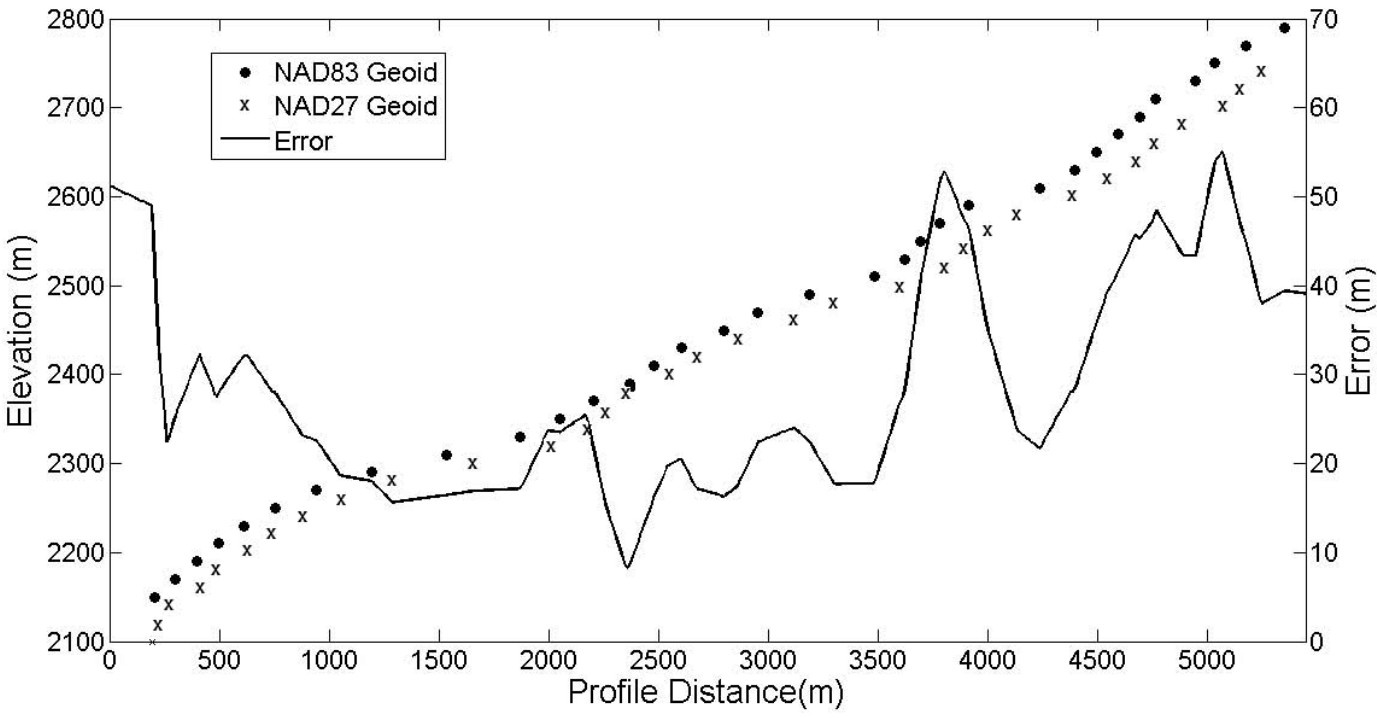

Fig. 7. Error occurring due to horizontal datum inconsistency on the surface of Peyto Glacier at the same epoch.

\section{TCD}

7, 55-101, 2013

\section{Sensitivity of alpine} glacial change detection and mass balance

T. Goulden et al.

Title Page

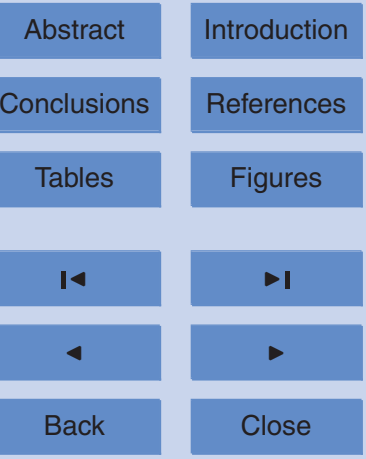

Full Screen / Esc

Printer-friendly Version

Interactive Discussion 


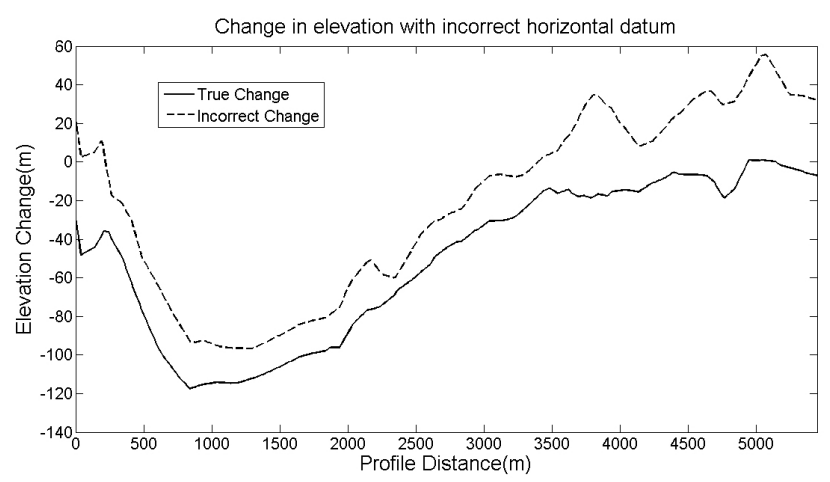

\section{Sensitivity of alpine glacial change detection and mass balance \\ T. Goulden et al.}

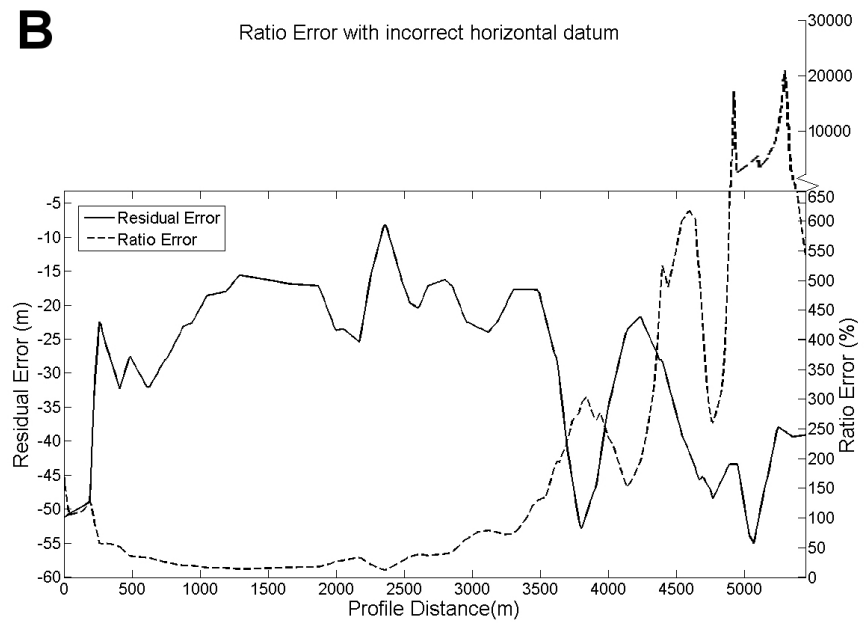

Title Page

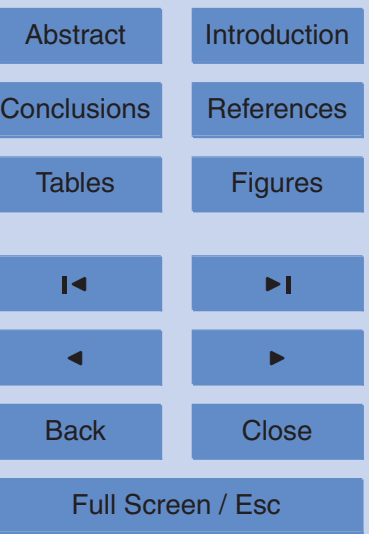

Printer-friendly Version

Fig. 8. Profiles of surface elevations (A) and change (B) for Peyto Glacier from 1966 to 2006 under correct and incorrect reconciliation of the horizontal datum.

Interactive Discussion 
A

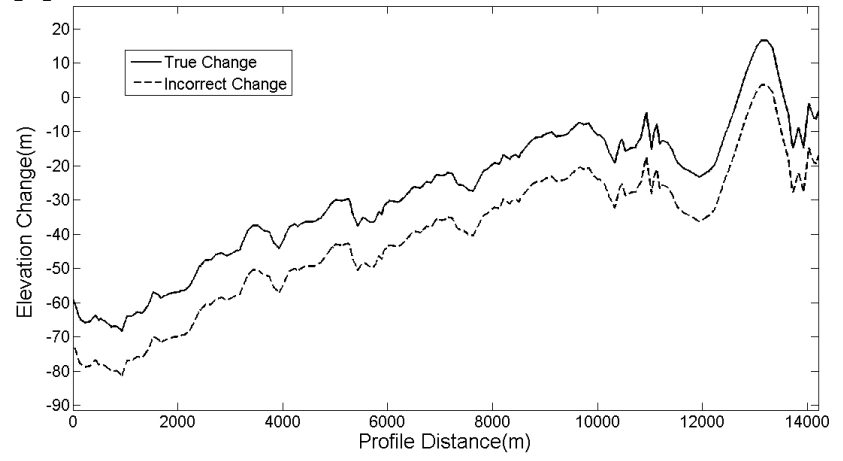

TCD

$7,55-101,2013$

\section{Sensitivity of alpine glacial change detection and mass balance \\ T. Goulden et al.}

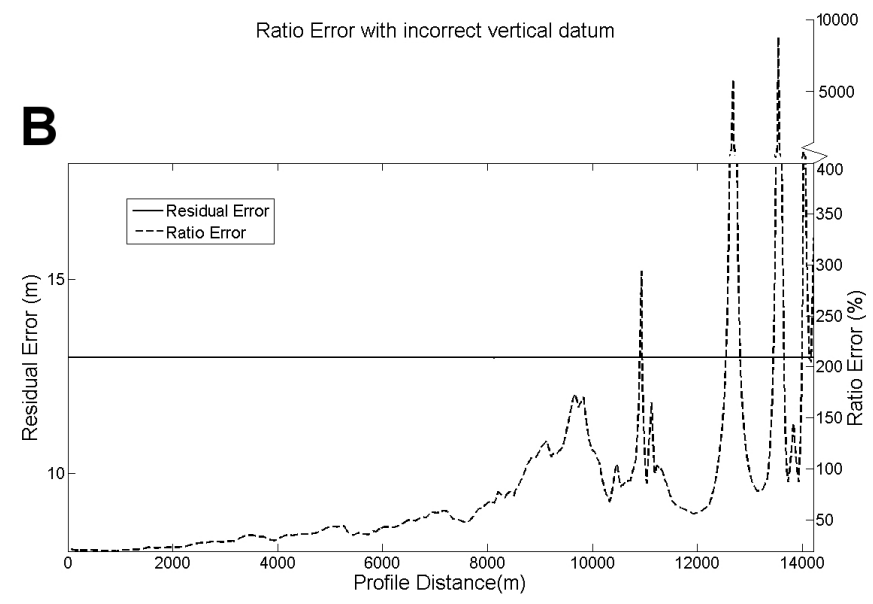

Title Page

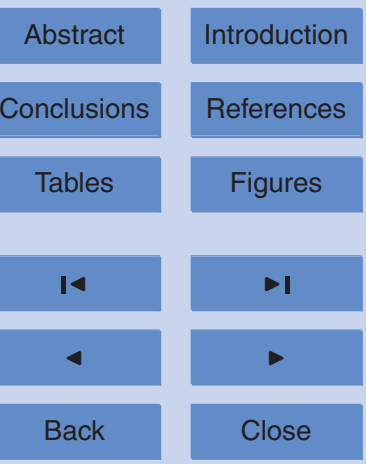

Full Screen / Esc

Fig. 9. Profiles of surface elevations (A) and change (B) for Bridge Glacier from 1988 to 2006 under correct and incorrect reconciliation of the vertical datum.

Printer-friendly Version

Interactive Discussion 